\title{
Impact of copper oxide nanomaterials on differentiated and undifferentiated Caco-2 intestinal epithelial cells; assessment of cytotoxicity, barrier integrity, cytokine production and nanomaterial penetration
}

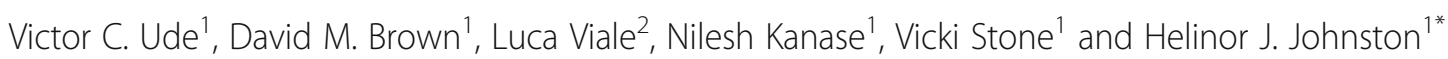

\begin{abstract}
Background: Copper oxide nanomaterials (CUO NMs) are exploited in a diverse array of products including antimicrobials, inks, cosmetics, textiles and food contact materials. There is therefore a need to assess the toxicity of $\mathrm{CuO}$ NMs to the gastrointestinal (Gl) tract since exposure could occur via direct oral ingestion, mucocillary clearance (following inhalation) or hand to mouth contact.

Methods: Undifferentiated Caco-2 intestinal cells were exposed to CuO NMs (10 nm) at concentrations ranging from 0.37 to $78.13 \mu \mathrm{g} / \mathrm{cm}^{2} \mathrm{Cu}$ (equivalent to 1.95 to $250 \mathrm{\mu g} / \mathrm{ml}$ ) and cell viability assessed $24 \mathrm{~h}$ post exposure using the alamar blue assay. The benchmark dose (BMD 20), determined using PROAST software, was identified as $4.44 \mu \mathrm{g} / \mathrm{cm}^{2}$ for $\mathrm{CuO} \mathrm{NMs}$, and $4.25 \mathrm{\mu g} / \mathrm{cm}^{2}$ for copper sulphate $\left(\mathrm{CuSO}_{4}\right)$, which informed the selection of concentrations for further studies. The differentiation status of cells and the impact of $\mathrm{CuO} \mathrm{NMs} \mathrm{and} \mathrm{CuSO}_{4}$ on the integrity of the differentiated Caco-2 cell monolayer were assessed by measurement of trans-epithelial electrical resistance (TEER), staining for Zonula occludens-1 (ZO-1) and imaging of cell morphology using scanning electron microscopy (SEM). The impact of CuO $\mathrm{NMs}$ and $\mathrm{CuSO}_{4}$ on the viability of differentiated cells was performed via assessment of cell number (DAPI staining), and visualisation of cell morphology (light microscopy). Interleukin-8 (IL-8) production by undifferentiated and differentiated Caco-2 cells following exposure to $\mathrm{CuO} \mathrm{NMs} \mathrm{and} \mathrm{CuSO}_{4}$ was determined using an ELISA. The copper concentration in the cell lysate, apical and basolateral compartments were measured with Inductive Coupled Plasma Optical Emission Spectrometry (ICP-OES) and used to calculate the apparent permeability coefficient ( $\left.P_{\text {app }}\right)$; a measure of barrier permeability to $\mathrm{CuO}$ NMs. For all experiments, $\mathrm{CuSO}_{4}$ was used as an ionic control.

Results: $\mathrm{CuO} \mathrm{NMs}$ and $\mathrm{CuSO}_{4}$ caused a concentration dependent decrease in cell viability in undifferentiated cells. $\mathrm{CuO} \mathrm{NMs}$ and $\mathrm{CuSO}_{4}$ translocated across the differentiated Caco-2 cell monolayer. CuO NM mediated IL-8 production was over 2-fold higher in undifferentiated cells. A reduction in cell viability in differentiated cells was not responsible for the lower level of cytokine production observed. Both $\mathrm{CuO} \mathrm{NMs}$ and $\mathrm{CuSO}_{4}$ decreased TEER values to a similar extent, and caused tight junction dysfunction (ZO-1 staining), suggesting that barrier integrity was disrupted.

(Continued on next page)
\end{abstract}

\footnotetext{
* Correspondence: h.johnston@hw.ac.uk

${ }^{1}$ Nano Safety Research Group, School of Engineering and Physical Sciences, Institute of Biological Chemistry, Biophysics and Bioengineering, Heriot-Watt University, Edinburgh EH14 4AS, UK

Full list of author information is available at the end of the article
} 
(Continued from previous page)

Conclusions: $\mathrm{CuO} \mathrm{NMs}$ and $\mathrm{CuSO}_{4}$ stimulated IL-8 production by Caco-2 cells, decreased barrier integrity and thereby increased the $\mathrm{P}_{\mathrm{app}}$ and translocation of $\mathrm{Cu}$. There was no significant enhancement in potency of the $\mathrm{CuO}$ NMs compared to $\mathrm{CuSO}_{4}$. Differentiated Caco-2 cells were identified as a powerful model to assess the impacts of ingested NMs on the Gl tract.

Keywords: Copper oxide nanomaterials, Caco-2, Toxicity, Interleukin-8, TEER, Translocation

\section{Background}

Copper $(\mathrm{Cu})$ is an essential micronutrient present in all tissues and is required for a plethora of cell functions including for example; peptide amidation, cellular respiration, pigment formation neurotransmitter biosynthesis and connective tissue strength $[1,2]$. $\mathrm{Cu}$ has also been implicated in the development and maintenance of both innate and acquired immunity [3, 4]. The pathogenesis of many neurological diseases (e.g. Alzheimer's disease, amyotrophic lateral sclerosis, Huntington's disease, Parkinson's disease) is associated with a disruption in $\mathrm{Cu}$ homeostasis [5, 6]. Excessive ingestion of copper by humans can cause gastrointestinal disturbance with symptoms such as nausea, vomiting, diarrhoea, and abdominal pain $[7,8]$.

Nanomaterials (NMs) have been used in wide ranging applications such as cosmetics, electronics, textiles, inks, pharmaceuticals and food contact materials [9, 10]. The anti- microbial properties of copper oxide nanomaterials $(\mathrm{CuO} \mathrm{NMs})$ are used in array of products such as textiles [11, 12], intrauterine devices [13], food contact materials [14] and wood preservation (due to its antifungal properties) [15]. $\mathrm{Cu}$ is relatively cheap and readily available and so the exploitation of $\mathrm{CuO}$ NMs has increased over recent years. For example, the antimicrobial properties of $\mathrm{CuO} \mathrm{NMs}$ could promote its use as an alternative to silver and gold NMs in products, to reduce their manufacturing cost [16]. $\mathrm{CuO} \mathrm{NMs}$ are also useful in heat transfer fluids and/or semiconductors [13, 17] and as inks [16, 18, 19].

A diverse array of NMs are available which vary with respect to their size, composition, surface area, charge, shape/structure and solubility. These physico-chemical properties can influence the biological response to NMs [20]. Metallic NMs (such as $\mathrm{CuO}$ ) can be soluble, and thus may elicit toxicity via particle and/or ion mediated effects. For this reason, ionic (metal salt) controls are often included in hazard studies [21-23] and NM solubility is commonly assessed using ICP-MS. Compared to other engineered NMs (such as silver $(\mathrm{Ag})$ and titanium dioxide $\left(\mathrm{TiO}_{2}\right)$; there are a limited number of studies which have assessed the hazard potential of $\mathrm{CuO}$ NMs. Impacts on the lung in vivo [24, 25] and on lung cells in vitro have been investigated. For example it has been demonstrated that $\mathrm{CuO}$ NMs $(42 \mathrm{~nm})$ were the most potent in terms of cytotoxicity and DNA damage to the A459 human lung epithelial cell line, compared to zinc oxide $(\mathrm{ZnO})$, iron complexes $\left(\mathrm{CuZnFe}_{2} \mathrm{O}_{4}, \mathrm{Fe}_{3} \mathrm{O}_{4}\right.$, and $\mathrm{Fe}_{2} \mathrm{O}_{3}$ ) and $\mathrm{TiO}_{2}$ [26]. The toxicity of $\mathrm{CuO}$ NMs on the liver, kidney, spleen (assessed in vitro and in vivo) and zebrafish has also been assessed to a limited extent [27-32]. However, there are a lack of studies that have investigated the toxicity of ingested $\mathrm{CuO}$ NMs, with existing studies focusing on investigation of their antimicrobial properties (as exploitation of this NMs often relies on this property).

Ingestion of $\mathrm{CuO} \mathrm{NMs}$ by humans is most likely to occur accidentally (e.g. due to leaching of $\mathrm{CuO}$ NMs from food contact materials into food). NMs may also enter the GI tract following inhalation in occupational, environmental and consumer settings due to clearance via the mucociliary escalator [33-35] or due to hand to mouth contact $[36,37]$. Currently, little is known about the risks associated with NM ingestion, despite the potential increase in NM ingestion by humans [38, 39]. Addressing this knowledge gap is therefore a research priority.

Due to the large number of diverse NMs whose safety needs to be assessed, it is important to align nanotoxicology studies to the 3Rs principles (Replacement, Reduction and Refinement of animal testing) [40]. Accordingly, the toxicity of ingested $\mathrm{CuO} \mathrm{NMs}$ was assessed in vitro in this study using the Caco- 2 cell line, which originates from a human colon adenocarcinoma [41]. Culturing of Caco-2 cells for 15-21 days, leads to their spontaneous differentiation to mature enterocytelike cells resembling the mature enterocytes of the small intestine in vivo, without growth factor supplementation [42-44]. During differentiation of the Caco-2 cell line, functional tight junctions joining the monolayers and well developed microvilli are formed at the apical (AP) membrane of mature enterocytes. [42]. In addition, the AP membrane of differentiated Caco- 2 cell line expresses the characteristic hydrolases such as sucroseisomaltase, lactase, aminopeptidase $\mathrm{N}$ and dipeptidyl peptidase IV characteristic of the absorptive enterocyte of small intestine microvilli [42, 45]. Undifferentiated Caco- 2 cells have been most commonly used to assess the toxicity of $\mathrm{NMs}$ (e.g. $\mathrm{TiO}_{2}, \mathrm{SiO}_{2}, \mathrm{ZnO}, \mathrm{MgO}, \mathrm{Ag}$ ) to the intestine in vitro [46-49]. The following endpoints 
have been prioritised within the assessment of NM toxicity to Caco-2 cells; cytotoxicity, cytokine production, oxidative stress and DNA damage as it is established that NMs often stimulate toxicity via inflammatory and oxidant driven responses. When differentiated Caco-2 cells have been used as a model to investigate the toxicity of ingested NMs, only limited endpoints (cytotoxicity, cytokine production, barrier integrity) have been assessed [50, 51]. Only one published study could be identified which investigated the toxicity of rod and spherical $\mathrm{CuO} \mathrm{NMs}$ to differentiated Caco-2 cells [51]. It was found that rod shaped NMs were more toxic than the spherical shaped $\mathrm{CuO} \mathrm{NMs}$ [51]. A comparison of the toxicity of $\mathrm{SiO}_{2}$ and $\mathrm{ZnO} \mathrm{NMs}$ in undifferentiated and differentiated Caco-2 cells has been performed via assessment of cytotoxicity, cytokine production, and it was found that undifferentiated cells were more sensitive to NM toxicity compared to differentiated cells [50]. The use of undifferentiated cells is quicker and cheaper than using the differentiated Caco-2 model. However, differentiated cells more accurately mimic in vivo conditions. Therefore, comparisons in the sensitivity of undifferentiated and differentiated cells are useful when developing a testing strategy to assess the toxicity of ingested NMs.

Transepithelial electrical resistance (TEER) is commonly used to monitor Caco-2 cell differentiation during culture. TEER of differentiated Caco-2 cells ranges from 260 up to $1200 \Omega . \mathrm{cm}^{2}$ depending on the experimental design (e.g. medium composition in the AP and basolateral compartments, and cell seeding density) [52]. TEER measurement is also a parameter that is commonly used to ascertain the integrity and viability of the cell monolayer in toxicity studies [53]. To date, no studies could be identified which assessed the impact of NMs on the integrity of the Caco-2 intestinal barrier over time via measurement of TEER. Differentiated Caco- 2 cells have been commomly used as an in vitro model to assess the translocation of substances (e.g. pharmaceuticals, pathogens) across the intestinal barrier $[54,55]$ and the rate of paracellular transport in differentiated Caco-2 cells has been demonstrated to be lower than that of the human intestine [56, 57].

Differentiated Caco-2 cells have been widely used to investigate the translocation of nanomedicines (e.g. polymers and liposomes) across the intestinal barrier, as reviewed Belogui et al. [58]. However, investigation of the translocation of other types of NMs has only been investigated to a limited extent previously. The translocation of $\mathrm{CuO} \mathrm{NMs}$ across the Caco-2 intestinal barrier in vitro has only been investigated in one study. It was demonstrated that $\mathrm{CuO} \mathrm{NM}$ transport was greater than that of $\mathrm{CuSO}_{4}$ [59], although the concentration of $\mathrm{Cu}$ was not standardized for $\mathrm{CuSO}_{4}$ and $\mathrm{CuO} \mathrm{NMs}$, making it challenging to compare the transport of these substances across the intestinal barrier. Of relevance is that the transport of other NMs has also been investigated in vitro and these studies have demonstrated how NM physico-chemical properties can influence their translocation. For example, translocation across the intestinal barrier and cytotoxic effects of a panel of zinc oxide ( $\mathrm{ZnO}) \mathrm{NMs}$ (of various sizes) has been studied using differentiated Caco-2 cells. It was observed that $\mathrm{ZnO} \mathrm{NMs}(20 \mathrm{~nm})$ had a higher level of permeation across the intestinal barrier and elicited greater cytotoxicity than larger particles (diameter of $1-5 \mu \mathrm{m}$ or 90 $200 \mathrm{~nm}$ ) [60], demonstrating that particle translocation across the intestinal barrier may be a size dependent phenomenon. There is also evidence that gold NMs (1.4 to $200 \mathrm{~nm}$ ) can translocate across the intestinal barrier of rats following ingestion [61]. However, in general there are a lack of studies which have investigated the influence of NMs on intestinal barrier integrity, and the impact this has on their translocation.

This study investigated the ability of $\mathrm{CuO} \mathrm{NMs}$ and $\mathrm{CuSO}_{4}$ to stimulate cytotoxicity and cytokine (IL-8) production in differentiated and undifferentiated Caco- 2 cells. The impact of $\mathrm{CuO} N \mathrm{NM}$ and $\mathrm{CuSO}_{4}$ on barrier integrity (via assessment of TEER, tight junction staining and cell morphology (i.e. presence of microvilli)) and their transport across intestinal epithelial cells in vitro was assessed in differentiated Caco- 2 cells. It is cheaper and quicker to perform studies using undifferentiated cells; however, the use of differentiated cells more accurately mimics the in vivo environment. Therefore, the advantages and limitations of using differentiated or undifferentiated Caco-2 models for assessment of NMs toxicity were also explored in this study.

\section{Methods}

Nanomaterial, characterisation and preparation

$\mathrm{CuO}$ NMs was obtained in powdered form from Plasma Chem, GmbH, Berlin, Germany, as a kind gift from project partners in the FP7 funded project Sustainable Nanotechnologies (SUN). The information data sheet from the supplier showed that it is a crystalline material with size of $15-20 \mathrm{~nm}$, specific surface area of $47 \mathrm{~m}^{2} / \mathrm{g}$ and a density of $6.3 \mathrm{~g} / \mathrm{cm}^{3}$ as determined using the BrunauerEmmett-Teller (BET) method. Detailed characterization of the size dissolution and surface chemistry of the $\mathrm{CuO}$ NMs by Transmission Electron Microscope (TEM), X-ray diffraction (XRD), and Inductive Coupled Plasma Optical Emission Spectrometry (ICP-OES) are available in Gosens et al. [25]. Briefly, $\mathrm{CuO}$ NMs has a primary particle size of $10 \mathrm{~nm}$ according to TEM analysis and $9.3 \mathrm{~nm}$ according to XRD. At pH $7.4<1.5 \%$ of $\mathrm{CuO}$ NMs were dissolved in Gamble's solution at 1 and $24 \mathrm{~h}$. In contrast at a pH of 4.5 
approximately $62 \%$ of the $\mathrm{CuO}$ NMs had dissolved in Gamble's solution at 1 and $24 \mathrm{~h}$ [25]. Copper sulphate $\left(\mathrm{CuSO}_{4}\right)$ was purchased from Sigma (Poole UK).

$\mathrm{CuO} \mathrm{NMs}$ and $\mathrm{CuSO}_{4}$ were dispersed following the procedure described by Jacobsen et al., [62]. Briefly, NMs or $\mathrm{CuSO}_{4}$ were dispersed in 2\% FCS in Milli Q deionised water and sonicated continuously in a bath sonicator for $16 \mathrm{~min}$. $\mathrm{CuO} \mathrm{NMs}$ or $\mathrm{CuSO}_{4}$ were then immediately diluted in cell culture medium (see below) to the required concentrations. The hydrodynamic diameter, zeta potential and polydispersity index (PdI) of $\mathrm{CuO}$ $\mathrm{NMs}$ in biological medium were determined using Dynamic Light Scattering (DLS, Malvern Zeta sizer Nano series) at $0 \mathrm{~h}$ and at $24 \mathrm{~h}$ (following incubation at $37{ }^{\circ} \mathrm{C}$ ). Following dispersion by sonication in $2 \% \mathrm{FCS}$, the concentration was adjusted to $50 \mu \mathrm{g} / \mathrm{ml} \mathrm{Cu}$ in phenol red free cell culture medium and the hydrodynamic diameter, PdI and Zeta potential were measured.

\section{Cell culture}

The human colon colorectal adenocarcinoma (Caco-2) cell line was obtained from the American Type Culture Collection (ATCC) (USA). The cells were maintained in minimum essential medium eagle (MEM) (Sigma) supplemented with $10 \%$ heat inactivated fetal bovine serum (FBS) (Gibco Life Technologies), $100 \mathrm{U} / \mathrm{ml}$ Penicillin/ Streptomycin (Gibco Life Technologies), $100 \mathrm{IU} / \mathrm{ml}$ nonessential amino acid (NEAA) (Gibco Life Technologies, Paisley, UK), and $2 \mathrm{mM} \mathrm{L}$ - glutamine (L-Glu) (Gibco Life Technologies) (termed complete cell culture medium) at $37{ }^{\circ} \mathrm{C}$ and $5 \% \mathrm{CO}_{2}$. The cells were subcultured using trypsin-EDTA (Gibco Life Technologies).

\section{Alamar blue cell viability assay: undifferentiated cells}

Caco-2 cells were seeded at a concentration of $1.56 \times 10^{5}$ cells $/ \mathrm{cm}^{2}$ into the wells of a 96 well plate (surface area $0.32 \mathrm{~cm}^{2}$ ) (Coaster Corning Flintshire, UK) and incubated for $24 \mathrm{~h}$ at $37{ }^{\circ} \mathrm{C}$ and $5 \% \mathrm{CO}_{2}$. At this time $100 \%$ confluency was reached. The cell culture medium was then removed, the cells were washed twice with phosphate buffered saline (PBS) (Gibco Life Technologies) and exposed to $100 \mu \mathrm{l}$ of either cell culture medium (control), 0.1\% Triton-X 100 (positive control) or $\mathrm{Cu}$ concentrations. The concentration of $\mathrm{Cu}$ in $\mathrm{CuO} \mathrm{NMs}$ and $\mathrm{CuSO}_{4}$ was standardised to ensure that cells were exposed to an equivalent concentration of $\mathrm{Cu}$ for each treatment, in all experiments. These concentrations were expressed on a mass basis of micro gram of $\mathrm{Cu}$ per centimetre square $\left(\mathrm{Cu} \mu \mathrm{g} / \mathrm{cm}^{2}\right)$. The concentrations used were 0.37 to $78.13 \mu \mathrm{g} / \mathrm{cm}^{2} \mathrm{Cu}$, which is equivalent to 1.95 to $250 \mu \mathrm{g} / \mathrm{ml}$.

At $24 \mathrm{~h}$ post-exposure, the cell supernatant was removed, stored at $-80{ }^{\circ} \mathrm{C}$ and replaced with alamar blue reagent (100 $\mu \mathrm{l}$, Sigma, Poole, UK) diluted to $0.1 \mathrm{mg} / \mathrm{ml}$ in cell culture medium. The cells were incubated for $4 \mathrm{~h}$ at $37{ }^{\circ} \mathrm{C}, 5 \% \mathrm{CO}_{2}$ and fluorescence measured at $560 /$ $590 \mathrm{~nm}$ (excitation/emission). Data was analysed using PROAST 38.9 software to obtain the Benchmark doseresponse (BMD) 20 (the concentration of $\mathrm{CuO}$ NMs that increase cell death by $20 \%$ ) and cell viability expressed in percentage of the untreated control. Concentrations of $2.22,3.17,4.44,6.34,8.88,12.68 \mu \mathrm{g} / \mathrm{cm}^{2}$ were selected for further study based on the findings from the Alamar blue assay.

\section{Caco-2 cell differentiation}

To obtain a differentiated Caco- 2 cell monolayer, cells were seeded at a concentration of $3.13 \times 10^{5}$ cells $/ \mathrm{cm}^{2}$ in $500 \mu \mathrm{l}$ cell culture medium which were added into the apical compartment of $3.0 \mu \mathrm{m}$ pore polycarbonate transwell inserts of a 12- well plate with growth area of $1.12 \mathrm{~cm}^{2}$ (Corning, Flintshire, UK). The basolateral (lower) compartments were filled with $1.5 \mathrm{ml}$ of cell culture medium. The cells were cultured at $37{ }^{\circ} \mathrm{C}, 5 \% \mathrm{CO}_{2}$ and $95 \%$ humidity for 16-21 days. The medium was changed every other day for the first 14 days and then every day until day 21 with fresh medium.

\section{Measurement of trans-epithelial electrical resistance (TEER)}

Trans-epithelial electrical resistance (TEER) were measured using an epithelial volt-ohmmeter EVOM2 (World precision instrument, Sarasota, USA). The resistance reading (in ohms) was taken once the reading had stabilized and measurements were taken every 2 days until day 21 . The resistivity was calculated using Eq. 1.

$$
\operatorname{Resistivity}\left(\Omega . c m^{2}\right)=o h m 2-o h m 1 \times A
$$

Where ohm $1=$ Resistance of the insert with cell culture medium only.

ohm 2 = Resistance of the insert with cell.

$\mathrm{A}=$ surface area of the insert in $\mathrm{cm}^{2}$.

TEER are reported as resistivity.

Only Caco-2 cell monolayers with TEER values greater than $500 \Omega . \mathrm{cm}^{2}$ were used for experiments. The impact of $\mathrm{CuO} \mathrm{NMs}$ and $\mathrm{CuSO}_{4}$ on the barrier integrity of differentiated Caco- 2 cells was studied by measuring TEER. Differentiated cells were exposed to cell culture medium (negative control), $0.1 \%$ triton X100 (positive control), $\mathrm{CuO} \mathrm{NMs}$ or $\mathrm{CuSO}_{4}$ (6.34 and $12.68 \mu \mathrm{g} / \mathrm{cm}^{2}$ ) and TEER measurements taken every $3 \mathrm{~h}$ for $15 \mathrm{~h}$ and at $24 \mathrm{~h}$ post exposure starting from time 0 (immediately after treatment with $\mathrm{CuO}$ $\mathrm{NMs}$ and $\mathrm{CuSO}_{4}$ ). 
Immunostaining of differentiated Caco-2 tight junctions Differentiated Caco-2 cells were exposed to cell culture medium (control), $\mathrm{CuO} \mathrm{NMs} \mathrm{or} \mathrm{CuSO}_{4}\left(6.34 \mu \mathrm{g} / \mathrm{cm}^{2}\right)$ and washed twice with PBS. The cells were fixed with 4\% formaldehyde for $25 \mathrm{~min}$ at RT and excess aldehyde groups were quenched with $50 \mathrm{mM}$ ammonium chloride for $10 \mathrm{~min}$ at RT. The cells were permeabilized with $0.1 \%$ triton X100 for $10 \mathrm{~min}$ and blocked for nonspecific binding with $10 \% \mathrm{BSA}$ for $2 \mathrm{~h}$ at RT. Cells were then incubated with $1 \mu \mathrm{g} / \mathrm{ml}$ anti-ZO1 tight junction protein antibody (Abcam, Cambridge, UK) diluted in 1\% BSA overnight $(\mathrm{o} / \mathrm{n})$ at $4{ }^{\circ} \mathrm{C}$. Next, cells were incubated with a secondary antibody, Alexa Fluor 488 goat anti-rabbit IgG H\&L (Abcam, Cambridge, UK) diluted to $4 \mu \mathrm{g} / \mathrm{ml}$ with $1 \%$ BSA for $1 \mathrm{~h}$ followed by nuclear staining with 4 , 6- diamido-2-phenylindole (DAPI, $300 \mathrm{nM}$ ) for $15 \mathrm{~min}$ at RT. Staining with DAPI was used to visualise the nuclei of cells and to assess cell number (as an indicator of cell viability). Cells were washed three times with PBS after each step. The polycarbonate inserts on which the differentiated Caco-2 cell monolayer was grown were carefully excised, mounted with mowoil and covered with a glass coverslip, which was sealed with nail polish. Cells were visualized using Zeiss LSM880 confocal microscope for ZO-1 or Zeiss fluorescent Microscope, Carl Zeiss Axio Scope A 1 Upright Research Microscope for nuclear counting (Germany) and the results analysed using the Zen program and Image $J$ software. Three fields of view (each of which was 140.80 X $105.60 \mu \mathrm{m}$ ) were analysed for each sample and the results were presented in mean number cells \pm SEM and then representative images presented.

\section{Imaging of cell morphology using light microscopy}

Differentiated Caco- 2 cells $\left(3.13 \times 10^{5}\right.$ cells $\left./ \mathrm{cm}^{2}\right)$ were grown for 21 days on $3.0 \mu \mathrm{m}$ pore polycarbonate transwell inserts of a 12- well plate (Coaster Corning, Flintshire, UK) while undifferentiated Caco-2 cells $\left(3.13 \times 10^{5}\right.$ cells $\left./ \mathrm{cm}^{2}\right)$ were grown on a glass coverslip in a 24 well plate (Coaster Corning, Flintshire, UK) for $24 \mathrm{~h}$. Both the differentiated and undifferentiated Caco-2 cells were exposed to cell culture medium (control), $6.34 \mu \mathrm{g} / \mathrm{cm}^{2} \mathrm{Cu}$ of $\mathrm{CuO} \mathrm{NMs}$ or $\mathrm{CuSO}_{4}$. After $24 \mathrm{~h}$, the cells were stained with Rapid Romanowsky stain (TCS Biosciences, England). Rapid Romanowsky stain combines the basic (cationic) dye, methylene blue (azure) and the acid (anionic) dye, eosin Y. The basic dye binds acid nuclei thereby generating a purple colour while the acid dye binds to the cytoplasm producing a red colour [63]. Briefly, Caco-2 cells were fixed with methanol, stained with eosin $\mathrm{Y}$ and counter stained with methylene blue. The cells were washed in distilled water dried and mounted with DPX mountant for histology (Sigma,
Poole UK). The cell were examined using light microscopy (magnification 40X).

\section{Scanning electron microscopy (SEM)}

For differentiated Caco- 2 cells, $3.13 \times 10^{5}$ cells $/ \mathrm{cm}^{2}$ were grown for 21 days on $3.0 \mu \mathrm{m}$ pore polycarbonate transwell inserts of a 12- well plate, with growth area of $1.12 \mathrm{~cm}^{2}$ (Coaster Corning, Flintshire, UK). For undifferentiated Caco- 2 cells, $3.13 \times 10^{5}$ cells $/ \mathrm{cm}^{2}$ were grown on a glass coverslip in a 24 well plate (Coaster Corning, Flintshire, UK) for $24 \mathrm{~h}$. Both the differentiated and undifferentiated Caco- 2 cells were treated with $12.68 \mu \mathrm{g} / \mathrm{cm}^{2} \mathrm{Cu}$ of $\mathrm{CuO}$ NMs. After $24 \mathrm{~h}$, the cells were washed with PBS twice, fixed with $5 \%$ glutaraldehyde in $0.1 \mathrm{M}$ sodium cacodylate for $2 \mathrm{~h}$ at $4{ }^{\circ} \mathrm{C}$. The cells were washed thrice with $0.1 \mathrm{M}$ sodium cacodylate and dehydrated in graded ethanol $(25,50,70,80$ and $90 \%)$ for $10 \mathrm{~min}$ in each ethanol grade at room temperature. The cells were further dehydrated in 100\% ethanol thrice for $15 \mathrm{~min}$ and then submerged in 2:1 fresh solution of hexamethyldisilazane (Sigma):100\% ethanol. The cells were finally dried in 100\% hexamethyldisilazane (Sigma), coated with gold and examined with Focus Ion Beam Scanning Electron Microscopy (FIB/SEM).

\section{Cytokine analysis}

Differentiated Caco-2 cells were exposed to cell culture medium (negative control), $200 \mathrm{ng} / \mathrm{ml}$ tumour necrosis alpha (TNF- $\alpha$ ) (positive control) 3.17, 6.34, or $12.68 \mu \mathrm{g} / \mathrm{cm}^{2} \mathrm{Cu}$ of $\mathrm{CuO} \mathrm{NMs}$ and $\mathrm{CuSO}_{4}$ for 24 or $48 \mathrm{~h}$. Undifferentiated Caco-2 cells were grown in a 96 well plate with a surface area of $0.32 \mathrm{~cm}^{2}$ (Coaster Corning Flintshire, UK). A concentration of $1.56 \times 10^{5}$ cells $/ \mathrm{cm}^{2}$ was seeded into the wells of the plate and incubated for $24 \mathrm{~h}$ at $37{ }^{\circ} \mathrm{C}$ and $5 \% \mathrm{CO}_{2}$ until $100 \%$ confluency was reached. Cells were then exposed to cell culture medium (control), $200 \mathrm{ng} / \mathrm{ml}$ TNF- $\alpha$ (positive control), 2.22, 3.17, 4.44, 6.34, 8.88 and $12.68 \mu \mathrm{g} / \mathrm{cm}^{2} \mathrm{Cu}$ of $\mathrm{CuO} \mathrm{NMs}$ or $\mathrm{CuSO}_{4}$ for 6 or $24 \mathrm{~h}$. The cell supernatants were collected from undifferentiated cells, and the apical and basolateral compartments of differentiated cells and stored in $-80{ }^{\circ} \mathrm{C}$ until required. On the day of cytokine analysis, the supernatants were thawed and IL-8 levels quantified using Enzyme-linked Immunosorbent assay (ELISA). Human IL-8 duo set ELISA kits were purchased from R\&D System, Inc., (Minneapolis, MN USA) and used for the cytokine analysis according to the manufacturer's protocol. Human IL- 8 production was measured using a microplate reader, SpectraMax M5 (California USA) at wavelength $450 \mathrm{~nm}$. 


\section{Translocation studies}

Differentiated Caco-2 cells were treated with cell culture medium (control), 3.17, 6.34 and $12.48 \mu \mathrm{g} / \mathrm{cm}^{2} \mathrm{Cu}$ of $\mathrm{CuO} \mathrm{NMs} \mathrm{or} \mathrm{CuSO}_{4}$ for 24 or $48 \mathrm{~h}$ at $37^{\circ} \mathrm{C}, 5 \% \mathrm{CO}_{2}$ and 95\% humidity and the cell culture medium then were removed from apical and basolateral compartments. Apical $(300 \mu \mathrm{l})$ and basolateral $(900 \mu \mathrm{l})$ media was digested with $5 \mathrm{ml}$ of $4 \% \mathrm{HNO}_{3}$ (Sigma), filtered with Puradisc $25 \mathrm{~mm}$ $0.2 \mu \mathrm{m}$ PES filter media (Whatman) and made up to $10 \mathrm{ml}$ with Milli Q deionised $\mathrm{H}_{2} \mathrm{O}$ to obtain final acidic concentration of $2 \% \mathrm{HNO}_{3}$. For cell preparation, the cells were digested following the method described by Bolea et al. [64]. Briefly, the cells were detached using $100 \mu \mathrm{l}$ of $25 \mathrm{mM}$ trypsin EDTA and $20 \% \mathrm{HNO}_{3}(1 \mathrm{ml})$ was added to the cells. The cells were then shaken with a rotatory shaker, PMS-1000, Grant-bio (Cambridge UK) at high speed for $4 \mathrm{~h}$, at RT. The solution was then diluted with Milli Q $\mathrm{H}_{2} \mathrm{O}$ to get an acidic concentration of $2 \% \mathrm{HNO}_{3}$, and then filtered with Puradisc $25 \mathrm{~mm} 0.2 \mu \mathrm{m}$ PES filter media (Whatman). The acidic extracts of medium and cell were analysed by ICP-OES using a Perkin Elmer Optima 5300 DV (USA), employing an RF forward power of $1400 \mathrm{~W}$, with argon gas flows of $15,0.2$ and $0.75 \mathrm{~L} / \mathrm{min}$ for plasma, auxiliary, and nebuliser flows, respectively.

Apparent permeability coefficients $\left(\mathrm{P}_{\text {app }}\right)$ of $\mathrm{Cu}$ was calculated using Eq. 2 [65].

$$
\operatorname{Papp}(\mathrm{cm} / \mathrm{s})=\frac{\Delta Q}{\Delta t} \times \frac{1}{A} \times C o
$$

Where $\Delta \mathrm{Q} / \Delta \mathrm{t}$ is the amount of $\mathrm{Cu}$ transported into the basolateral compartment per unit time $(\mathrm{t}), \mathrm{A}$ is the surface area of the insert (Caco-2 cell monolayer) and Co is the initial concentration of the substance in the donor (apical) compartment.

\section{Data analysis}

Each experiment was repeated at least three times (on different days) for undifferentiated and differentiated cells and all data generated from these experiments are expressed as the mean \pm standard error of the mean (SEM). The figures were generated using Graph pad Prism. After checking normality of the data, a one-way analysis of variance (ANOVA) followed by the Tukeys multiple comparison was employed to investigate statistical significance using Minitab 17 software. PROAST version 38.9 software was used to analyse Benchmark dose-response.

\section{Results}

\section{Physico-chemical characteristics of the CuO NMs}

Here, we analysed the hydrodynamic diameter, zeta potential and polydispersity index (PdI) of $\mathrm{CuO} \mathrm{NMs}$ in cell culture medium at 0 and $24 \mathrm{~h}$ post incubation at
$37{ }^{\circ} \mathrm{C} 5 \%, \mathrm{CO}_{2}$ and $95 \%$ humidity. $\mathrm{CuO} \mathrm{NMs}$ were highly agglomerated in complete cell culture medium at $0 \mathrm{~h}$, as the average hydrodynamic diameter was $157 \mathrm{~nm}$, whilst the primary particle size measured by TEM was $10 \mathrm{~nm}$ [25]. After incubation for $24 \mathrm{~h}$ at $37{ }^{\circ} \mathrm{C}, 5 \%, \mathrm{CO}_{2}$ and $95 \%$ humidity in complete cell culture medium, a significant decrease in hydrodynamic diameter (to $24 \mathrm{~nm}$ ) and PdI was observed. The zeta potential remained constant and negative at 0 and $24 \mathrm{~h}$. The PdI at 0 and $24 \mathrm{~h}$ time points were less than one, indicating that $\mathrm{CuO}$ NMs suspensions were suitable for DLS analysis (Table 1).

The solubility of $\mathrm{CuO} \mathrm{NMs}$ following dispersion in MEM and DMEM was analysed using ICP-OES and showed that 47.79 and $53.53 \% \mathrm{CuO} \mathrm{NMs}$ dissociated to $\mathrm{Cu}^{2+}$ in MEM after 1 and $24 \mathrm{~h}$ respectively and in DMEM this was 59.91 and $67.41 \%$ at 1 and $24 \mathrm{~h}$ (Additional file 1). This indicates greater solubility of $\mathrm{CuO} \mathrm{NMs}$ in medium compare to Gamble's solution at physiological $\mathrm{pH}$, which was previously identified to be $\sim 1.5 \%$ [25]. Further information on $\mathrm{CuO}$ NMs characterisation from existing studies is provided in the methods section.

\section{Impact of CuO NMs on viability of undifferentiated Caco-2 cell}

A concentration dependent decrease in undifferentiated Caco-2 cell viability was observed after treatment with $\mathrm{CuO} \mathrm{NMs}$ and $\mathrm{CuSO}_{4}$ for $24 \mathrm{~h}$ (Fig. 1a). At concentrations below $1.22 \mu \mathrm{g} / \mathrm{cm}^{2} \mathrm{Cu}$ of $\mathrm{CuO} \mathrm{NMs}$, there was little or no impact on the viability of undifferentiated Caco-2 cells. Cell viability significantly decreased in a concentration dependent manner on exposure to 2.44 to $19.53 \mu \mathrm{g} /$ $\mathrm{cm}^{2} \mathrm{Cu}$ of $\mathrm{CuO}$ NMs reaching $90 \%$ cell death at concentrations above $19.53 \mu \mathrm{g} / \mathrm{cm}^{2} \mathrm{Cu}$ of $\mathrm{CuO}$ NMs after $24 \mathrm{~h}$. $\mathrm{CuSO}_{4}$ also followed the same pattern. No significant difference between the toxicity of $\mathrm{CuO} N \mathrm{NM}$ and $\mathrm{CuSO}_{4}$ was observed when concentration was expressed as $\mu \mathrm{g} /$ $\mathrm{cm}^{2} \mathrm{Cu}$ (Fig. 1a). Using Proast 38.9 software, the concentration of $\mathrm{CuO} \mathrm{NMs}$ and $\mathrm{CuSO}_{4}$ required to kill $20 \%$ of the cells were 4.44 and $4.25 \mu \mathrm{g} / \mathrm{cm}^{2} \mathrm{Cu}$ respectively (Fig. 1b). This informed the selection of the following

Table 1 Hydrodynamic diameter, zeta potential and Pdl values after dispersion of $50 \mathrm{\mu g} / \mathrm{ml} \mathrm{Cu}$ of CuO NMs in complete cell culture medium

\begin{tabular}{llll}
\hline Time $(\mathrm{h})$ & Hydrodynamic diameter $(\mathrm{nm})$ & Zeta Potential & Pdl \\
\hline 0 & $157.37 \pm 29.44^{*}$ & $-7.38 \pm 0.59$ & $0.6 \pm 0.07^{*}$ \\
24 & $24.01 \pm 0.56$ & $-7.29 \pm 0.05$ & $0.42 \pm 0.1$
\end{tabular}

CuO NMs were dispersed in 2\% FCS in water, sonicated and then diluted in complete cell culture medium and the hydrodynamic diameter, zeta potential and Pdl were measured immediately $(0 \mathrm{~h})$ or following incubation at $37^{\circ} \mathrm{C}$, $5 \%, \mathrm{CO}_{2}$ and $95 \%$ humidity for $24 \mathrm{~h}$. Data expressed as Mean \pm SEM $(n=3)$. Asterisk $(*)$ represents significance when incubation at time point 0 and $24 \mathrm{~h}$ are compared $P<0.05$ 

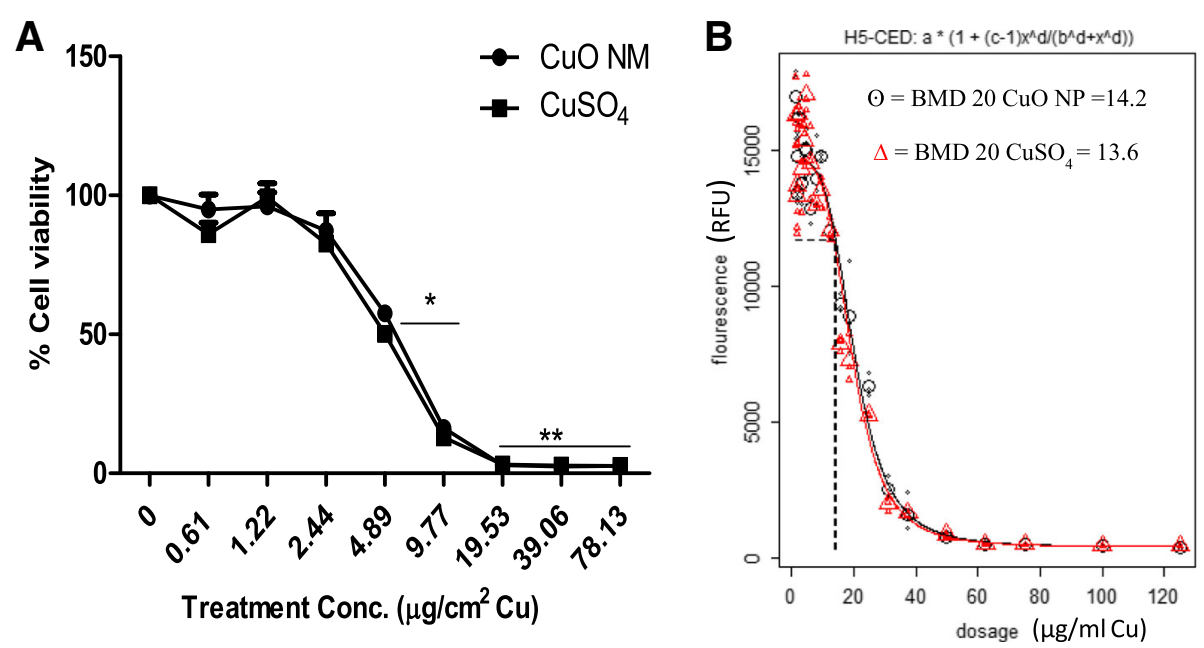

Fig. 1 Cytotoxicity of CuO NMs and $\mathrm{CuSO}_{4}$ to undifferentiated Caco-2 cells. Viability of undifferentiated Caco-2 cells was assessed using the alamar blue assay following exposure of cells to cell culture medium (control), $\mathrm{CuO} \mathrm{NMs} \mathrm{or} \mathrm{CuSO}_{4}$ at concentrations ranging from 0.61 and $78.13 \mathrm{\mu g} / \mathrm{cm}^{2}$ Cu for 24 h. a) Viability of Caco-2 cells following CuO NMs or $\mathrm{CuSO}_{4}$ exposure expressed as a \% of the control. b) Determination of $20 \%$ Benchmark dose (BMD 20) in $\mathrm{mg} / \mathrm{ml}$ following exposure of undifferentiated Caco-2 cells to CuO NMs or $\mathrm{CuSO}_{4}$ exposure. Data was analysed using Proast 38.9 software to obtain the BMD 20. Data are expressed in mean \pm SEM $(n=3)$ and * represents significance compared to control at $P<0.05$

sub-lethal concentrations of $\mathrm{CuO} \mathrm{NMs}$ and $\mathrm{CuSO}_{4}$ $\left(2.22,3.17,4.44,6.34,8.88\right.$ and $\left.12.68 \mu \mathrm{g} / \mathrm{cm}^{2} \mathrm{Cu}\right)$ to test in further studies.

\section{Impact of $\mathrm{CuO} \mathrm{NMs}$ and $\mathrm{CuSO}_{4}$ on morphology and integrity of differentiated Caco-2 cell monolayer}

Differentiation of Caco-2 cell monolayer was evidenced by the maintenance of TEER value between 823.67 and $861.33 \Omega . \mathrm{cm}^{2}$ over 21 days, which showed no significant difference over the duration of the experiment $(24 \mathrm{~h})$ for control cells (Fig. 2a). Staining for the tight junction protein Zonula occludens -1 (ZO-1) (Fig. 3a) also confirmed that the differentiation of Caco-2 was successful. In contrast, no tight junction protein (Additional file 2) or microvilli were observed for undifferentiated Caco-2 cells. According to SEM images (Fig. 3b), both differentiated and undifferentiated Caco- 2 control cells covered the entire surface, indicating that they were confluent. However, differentiated Caco-2 control cells had microvilli, which were lacking in undifferentiated Caco- 2 cells.

The TEER value of the differentiated Caco- 2 cell monolayer treated with 6.34 and $12.68 \mu \mathrm{g} / \mathrm{cm}^{2} \mathrm{Cu}$ of $\mathrm{CuO} \mathrm{NMs}$ and $\mathrm{CuSO}_{4}$ respectively remained relatively constant and equivalent to the control until $9 \mathrm{~h}$ post exposure. At 12 and $15 \mathrm{~h}, \mathrm{CuO} \mathrm{NMs}$ and $\mathrm{CuSO}_{4}$ induced a significant decrease in TEER values at all concentrations tested (Fig. 2a). At $24 \mathrm{~h}$, the greatest reduction in TEER value was observed; the TEER value for both $\mathrm{CuO}$ NMs and $\mathrm{CuSO}_{4}$ was significantly lower than negative control cells at both concentrations tested (6.34 and $12.68 \mu \mathrm{g} / \mathrm{cm}^{2} \mathrm{Cu}$ ). For the positive control (Triton
$\mathrm{X} 100)$, the TEER value decreased to $23 \pm 0.52 \Omega . \mathrm{cm}^{2}$ after $3 \mathrm{~h}$. There was no significant difference between the changes in TEER induced by either $\mathrm{CuO}$ NMs or $\mathrm{CuSO}_{4}$ at all-time points investigated. Cells treated with $6.34 \mu \mathrm{g} / \mathrm{cm}^{2} \mathrm{Cu}$ of $\mathrm{CuO} \mathrm{NMs}$ or $\mathrm{CuSO}_{4}$ for $24 \mathrm{~h}$ also exhibited a reduced degree of tight junction protein staining compared to control (Fig. 3a).

The microvilli of differentiated Caco- 2 cells exposed to $\mathrm{CuO}$ NMs were shortened and crypt-like (Fig. 3b). However, there was no obvious loss of cells. It was not possible to perform the Alarmar Blue assay on the transwell insert used to culture differentiated cells, or conduct the $\mathrm{LDH}$ assay due to $\mathrm{Cu}$ interference in this assay [66]. Therefore, in order to assess the impact of $\mathrm{CuO}$ NMs and $\mathrm{CuSO}_{4}$ on the viability of differentiated cells, cells were imaged using light microscopy, and in addition, cell number was counted via DAPI staining. Light microscopy (Fig. 2b) and SEM (Fig. 3b) images revealed that there was a loss of undifferentiated Caco-2 cells following exposure to $\mathrm{CuO} N \mathrm{NM}$ or $\mathrm{CuSO}_{4}$ however, no loss of differentiated cells was observed. There were significantly less undifferentiated control cells, as indicated by a decrease in nuclei number, compared to differentiated Caco-2 cells (in an equivalent field of view: 140.80 X $105.60 \mu \mathrm{m}$ ) (Fig. 2c and d). No change in the number of differentiated cells was observed following exposure to $\mathrm{CuO} N \mathrm{NMs}$ or $\mathrm{CuSO}_{4}$ for $24 \mathrm{~h}$ (Fig. 2c and d). These findings suggest that $\mathrm{CuO}$ NMs or $\mathrm{CuSO}_{4}$ do not affect viability of differentiated Caco-2 cells at the concentrations and time point tested. 

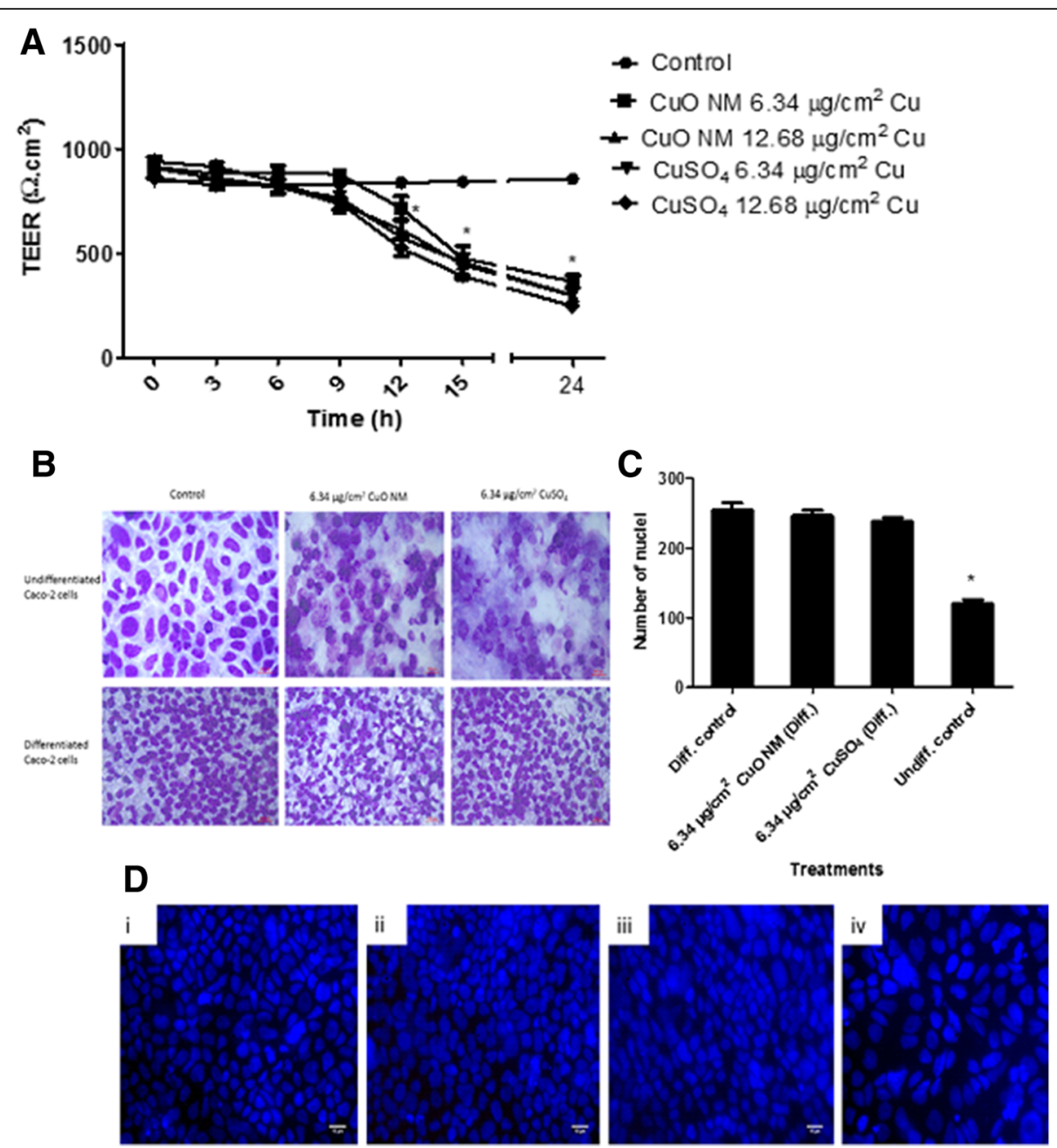

Fig. 2 Impact of $\mathrm{CuO} \mathrm{NMs} \mathrm{and} \mathrm{CuSO}_{4}$ on the differentiated and undifferentiated Caco-2 cell monolayer. a) Impact of CuO NMs and CuSO ${ }_{4}$ on differentiated Caco-2 cell TEER values. Following differentiation, Caco-2 cells were exposed to cell culture medium (control, 0), CuO NMs or $\mathrm{CuSO}_{4}$ at concentrations of 6.34 or $12.68 \mu \mathrm{g} / \mathrm{cm}^{2} \mathrm{Cu}$ at the apical compartment. The TEER values were measured using epithelial volt-ohmmeter EVOM every $3 \mathrm{~h}$. Data are expressed in mean TEER value \pm SEM $(n=3)$ and * represents significant difference compared to control at $P<0.05$. b) Differentiated and undifferentiated Caco-2 cell morphology following exposure to CuO NM or $\mathrm{CuSO}_{4}$. Cells were exposed to control (cell culture medium) and $6.34 \mathrm{\mu g} / \mathrm{cm}^{2} \mathrm{Cu} \mathrm{CuO} \mathrm{NM}$ or $\mathrm{CuSO}_{4}$ for $24 \mathrm{~h}$. The cells were fixed, stained and visualised using the light microscopy (magnification 40X, scale bar $=500 \mu \mathrm{m}$. c) Total nuclei count of differentiated and undifferentiated Caco-2 cells. d) Representative image of nuclei staining with DAPI (field of view: $140.80 \times 105.60 \mu \mathrm{m}$ ). i) Untreated differentiated Caco-2 cell, ii) differentiated Caco-2 cell treated with $6.34 \mu \mathrm{g} / \mathrm{cm}^{2} \mathrm{Cu} \mathrm{CuO}$ NM, iii) differentiated Caco-2 cell treated with $6.34 \mu \mathrm{g} / \mathrm{cm}^{2} \mathrm{Cu} \mathrm{CuSO}_{4}$ and iv) untreated undifferentiated Caco-2 cell. For $\mathbf{c}$ and $\mathbf{d}$, the nucleus were stained with DAPI and the images obtained with Zeiss fluorescent Microscope, Carl Zeiss Axio Scope A 1 Upright Research Microscope (magnification 40X) and the results analysed using Image J software. Scale bar $=10 \mu \mathrm{m}$

\section{IL-8 production by differentiated and undifferentiated \\ Caco- 2 cells}

At $6 \mathrm{~h}$ undifferentiated cells exposed to $\mathrm{CuO} \mathrm{NMs}$ or $\mathrm{CuSO}_{4}$ did not stimulate a significant increase in IL-8 production compared to control (Fig. 4a). In contrast, at $24 \mathrm{~h}$ undifferentiated Caco-2 cells treated with $\mathrm{CuO}$ $\mathrm{NMs}$ and $\mathrm{CuSO}_{4}$ demonstrated a significant increase in IL-8 production with up to approximately $1000 \mathrm{pg} / \mathrm{ml}$ of IL-8 produced at a concentration of $4.44 \mu \mathrm{g} / \mathrm{cm}^{2}$. For differentiated cells, IL-8 production increased to approximately $400 \mathrm{pg} / \mathrm{ml}$ following exposure to both $\mathrm{CuO}$
$\mathrm{NMs}$ and $\mathrm{CuSO}_{4}$ at 24 and $48 \mathrm{~h}$ post exposure, compared to control (Fig. 4b). Both $\mathrm{CuO} N M s$ and $\mathrm{CuSO}_{4}$ therefore stimulated a concentration and time dependent increase in IL-8 production in both differentiated and undifferentiated Caco- 2 cells. However, comparison of IL-8 production by differentiated and undifferentiated Caco-2 cells demonstrated that the cytokine production at $24 \mathrm{~h}$ was significantly greater for undifferentiated Caco-2 cells (Fig. 4c). The lower level of cytokine production observed in differentiated cells is unlikely to be a consequence of a loss of cell 


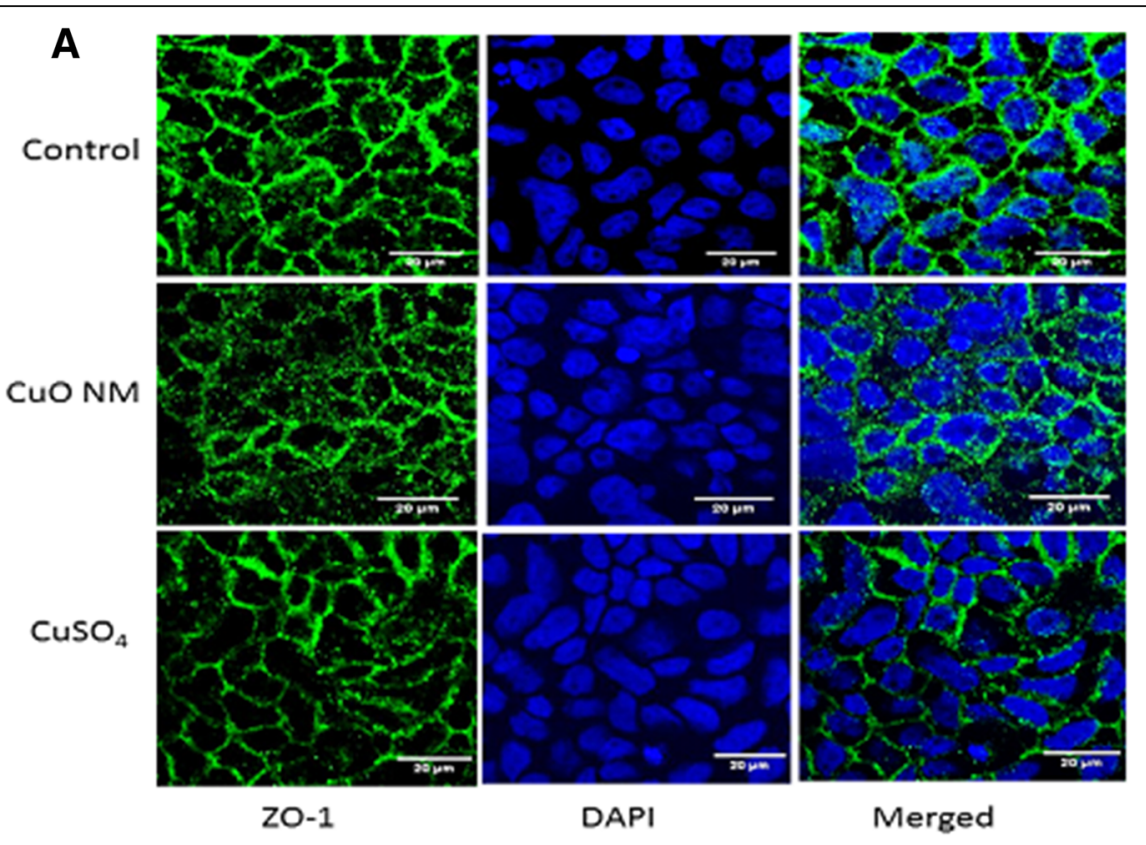

B

Differentiated Caco-2 cells

Undifferentiated Caco-2 cells
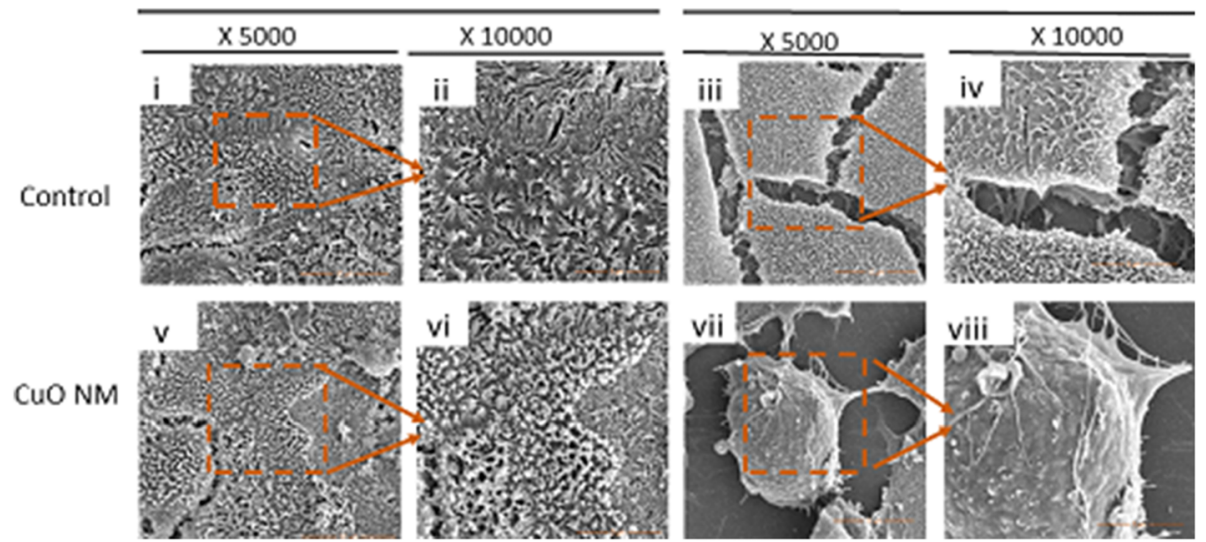

Fig. 3 The impact of $\mathrm{CuO} \mathrm{NMs} \mathrm{and} \mathrm{CuSO}_{4}$ on Caco-2 cell morphology. a) Following differentiation, cell monolayers were exposed to cell culture medium (control) or $6.34 \mathrm{\mu g} / \mathrm{cm}^{2} \mathrm{Cu}$ of $\mathrm{CuO} \mathrm{NMs}$ and $\mathrm{CuSO}_{4}$ for $24 \mathrm{~h}$ and then fixed and stained for the tight junction protein ZO-1 (green) and nucleus with DAPI (blue). The images were obtained with Zeiss LSM880 confocal microscope using the Zen program for data analyses. Scale bar $=20 \mu \mathrm{m}$. b) Assessment of cell morphology using SEM. Differentiated and undifferentiated Caco-2 cells were exposed to $12.68 \mu \mathrm{g} / \mathrm{cm}^{2} \mathrm{Cu}$ of $\mathrm{CUO}$ NMs for $24 \mathrm{~h}$ and then were washed, fixed, dehydrated, dried and examined by FIB/SEM. i and ii are control differentiated Caco-2 cells enlarged X 5000 and X 10000 respectively. iii and iv are control undifferentiated Caco-2 cells enlarged X 5000 and X 10000 respectively. $v$ and vi are differentiated Caco-2 cells exposed to $12.68 \mu \mathrm{g} / \mathrm{cm}^{2}$ Cu of CuO NMs enlarged X 5000 and X 10000 respectively and vii and viii are undifferentiated Caco-2 cells exposed to $12.68 \mu \mathrm{g} / \mathrm{cm}^{2}$ Cu of CuO NMs enlarged X 5000 and X 10000 respectively

viability (Fig. $2 \mathrm{~b}$ and c). There was no significant difference in IL-8 production between $\mathrm{CuO} N M$ and $\mathrm{CuSO}_{4}$ treated cells for either differentiated or undifferentiated Caco- 2 cell models. Differentiated and undifferentiated Caco- 2 cells treated with $200 \mathrm{ng} / \mathrm{ml} \mathrm{TNF-} \alpha$ as positive control secreted $89.60 \pm 4.77$ and $275 \pm 35.04 \mathrm{pg} / \mathrm{ml}$ respectively. IL-8 was below the limit of detection in the medium collected at the basolateral compartment of differentiated Caco-2 cells (data not shown).

\section{Translocation of copper across differentiated Caco-2 monolayer}

In all experiments assessing the translocation of $\mathrm{Cu}$ across the differentiated Caco- 2 cell monolayer, $\mathrm{CuO} \mathrm{NMs}$ or $\mathrm{CuSO}_{4}$ were added directly to the apical compartment at time $0 \mathrm{~h}$. The concentration of soluble $\mathrm{Cu}$ in the apical chamber of the cells was both concentration and time dependent. For the lowest concentration of $\mathrm{CuO} \mathrm{NMs}$ and $\mathrm{CuSO}_{4}$ almost the entire initial dose $(87.26 \pm 3.88$ to $96.35 \pm 3.15 \%)$ was detectable in the apical chamber after 


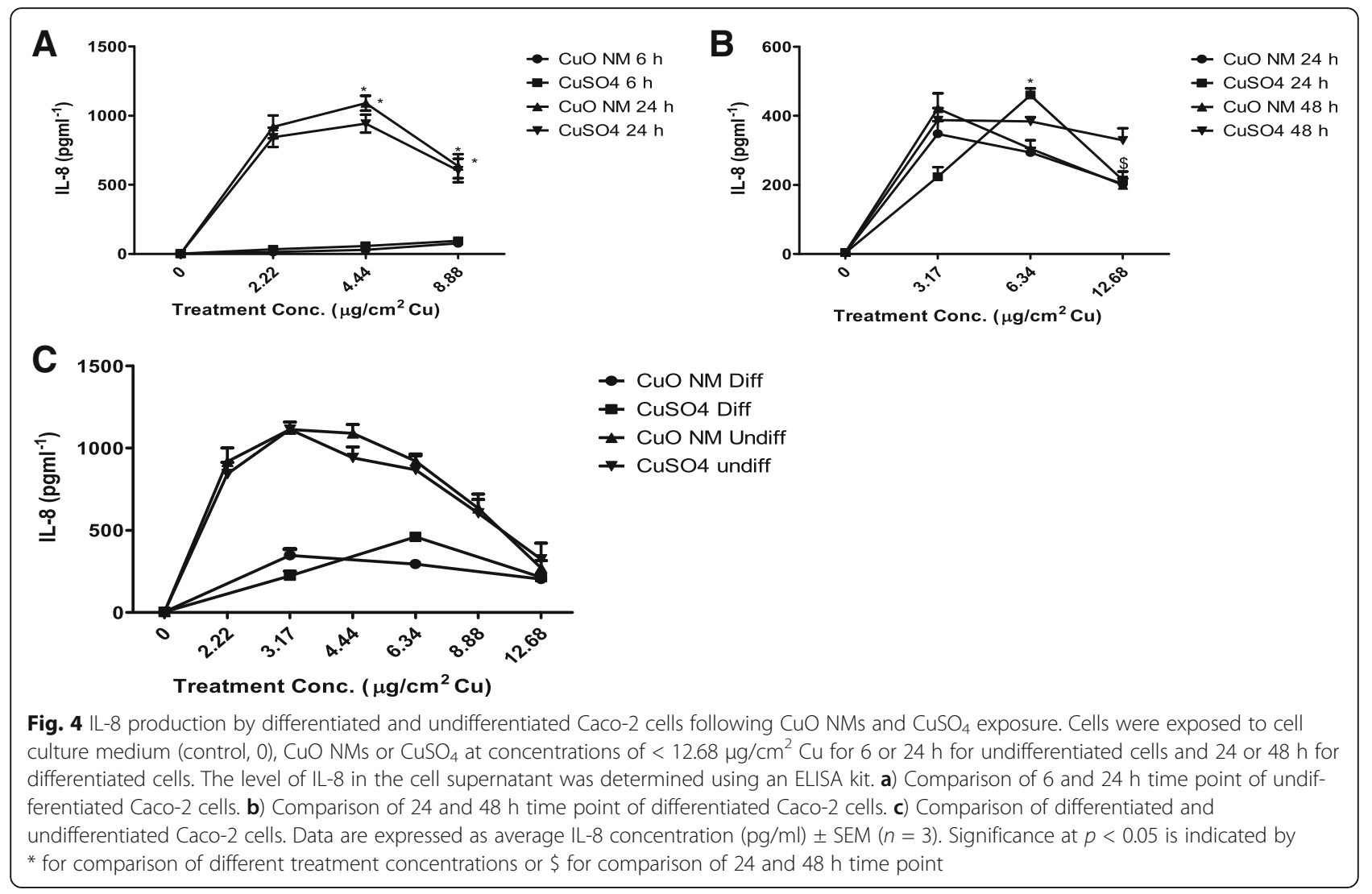

$24 \mathrm{~h}$ of exposure, declining slightly $(77.91 \pm 1.01$ to $85.74 \pm 5.83 \%$ ), after $48 \mathrm{~h}$. In contrast, for the highest concentration of $\mathrm{CuO}$ NMs and $\mathrm{CuSO}_{4}$ approximately $58.07 \pm 4.29$ to $61.17 \pm 10.10 \%$ was detectable in the apical compartment after $24 \mathrm{~h}$ exposure with a significant $(P<0.05)$ further decrease to between $27.00 \pm 2.70$ to $28.77 \pm 3.30 \%$ after $48 \mathrm{~h}$ exposure (Fig. $5 \mathrm{a}$ ).

Again, translocation measured as the content of copper in the basolateral chamber was concentration and time dependent. Therefore, the concentration of $\mathrm{Cu}$ in the basolateral media was greatest for cells exposed to $\mathrm{CuO} \mathrm{NMs}$ and $\mathrm{CuSO}_{4}$ at the highest concentration of $12.68 \mu \mathrm{g} / \mathrm{cm}^{2} \mathrm{Cu}$, and longest time point of $48 \mathrm{~h}$. Transport of $\mathrm{Cu}$ to the basolateral compartment also increased significantly from $24 \mathrm{~h}$ to $48 \mathrm{~h}$ for $\mathrm{CuSO}_{4}(3.17$ and $6.34 \mu \mathrm{g} / \mathrm{cm}^{2} \mathrm{Cu}$ respectively) at $24 \mathrm{~h}$ post exposure of the same concentration (Fig. 5b). The cellular uptake of $\mathrm{CuO} \mathrm{NMs}$ or $\mathrm{CuSO}_{4}$ was $<3 \%$ of the initial exposure dose at 24 and $48 \mathrm{~h}$, for all concentrations tested (Fig. 5c). There was no significant retention of $\mathrm{Cu}$ in the cell monolayer for both $\mathrm{CuO} \mathrm{NMs}$ and $\mathrm{CuSO}_{4}$ and $\mathrm{Cu}$ was not detected in the untreated control cells. No difference was observed between $\mathrm{CuO} N \mathrm{NM}$ and $\mathrm{CuSO}_{4}$ for transport and uptake.

When the data is re-expressed as the apparent permeability coefficient $\left(\mathrm{P}_{\mathrm{app}}\right)$, again a time and concentration dependent increase in permeability was observed following exposure of differentiated Caco-2 cells to $\mathrm{CuO}$ NMs and $\mathrm{CuSO}_{4}$. Both $\mathrm{CuO} \mathrm{NMs}$ and $\mathrm{CuSO}_{4}$ significantly increased $\mathrm{P}_{\mathrm{app}}$ of the Caco- 2 cell monolayer at 24 and $48 \mathrm{~h}$ at a concentration of $12.68 \mu \mathrm{g} / \mathrm{cm}^{2} \mathrm{Cu}$. At $48 \mathrm{~h}$ $\mathrm{CuSO}_{4}$ stimulated a greater enhancement in $\mathrm{P}_{\text {app }}$ than $\mathrm{CuO} \mathrm{NMs}$, with a significant increase in permeability observed at concentrations of 14.2 and $28.4 \mu \mathrm{g} / \mathrm{ml} \mathrm{Cu}$ (Fig. 6).

\section{Discussion}

Despite the anticipated increase in $\mathrm{CuO}$ NM ingestion by humans associated with their increased use, there is a lack of understanding about the toxicity of $\mathrm{CuO}$ NMs to the GI tract. Indeed, assessment of the hazard of ingested NMs is recognised as a research priority as only limited number of studies have assessed the toxicity of ingested NMs [38, 67]. This study clearly demonstrates that the impacts of $\mathrm{CuO} \mathrm{NMs}$ are entirely comparable to $\mathrm{CuSO}_{4}$ in a standard differentiated in vitro Caco-2 model of the GI tract for endpoints spanning TEER, cell morphology, tight junction integrity, translocation and IL-8 production. The comparable results of $\mathrm{CuSO}_{4}$ suggest that $\mathrm{CuO}$ NMs induced its effect, in part by an ion mediated mechanism. 


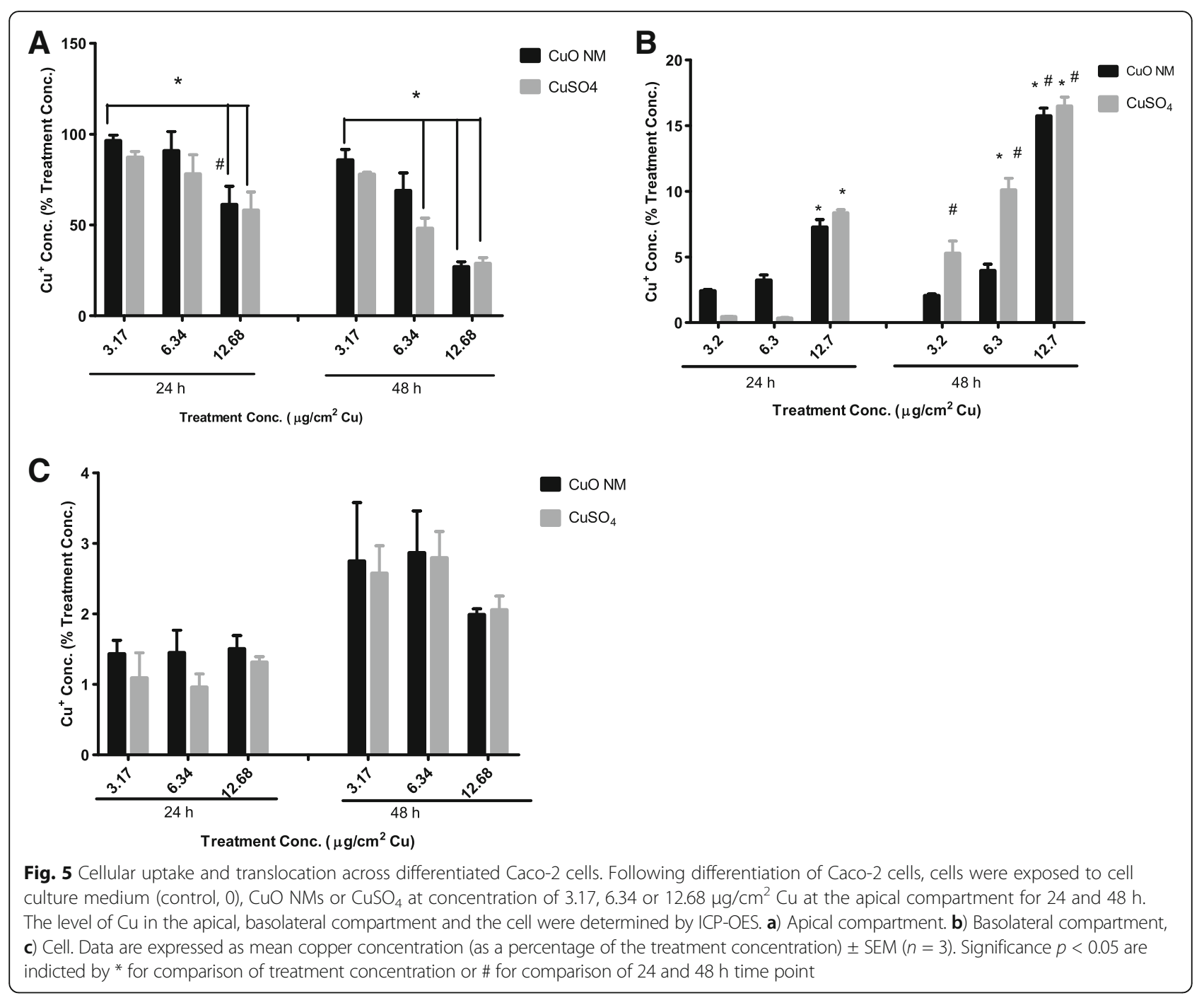

\section{Cytotoxicity}

Viability studies were carried out using undifferentiated Caco-2 cells to obtain a BMD 20 value. BMD is useful in estimating the concentration of a toxicant required to elicit a low, but measurable (sub lethal), toxic response. BMD eliminates the problems associated with determination of the of no-observed-effect-level (NOEL) as it uses full dose-response data in the statistical analysis thereby enhancing quantification of uncertainty in the data [68]. Although differentiated Caco-2 cells are considered to be more representative of cells in vivo, undifferentiated cells were used initially to screen cytotoxicity, as it is technically easier, quicker and cheaper to perform these studies and so a wider range of concentrations can be tested. Furthermore, the transwell inserts used to support the growth of differentiated Caco-2 cells are not compatible with the Alamar Blue Assay (which was used to assess the viability of undifferentiated cells). $\mathrm{CuO}$ NMs are also known to interfere with LDH assay (which uses the cell supernatant to assess cytotoxicity) [66] making it unreliable to perform this assay for $\mathrm{CuO}$ NMs. Therefore, it is more challenging to evaluate cytotoxicity and derive BMD with differentiated Caco-2 cells in transwell inserts. Accordingly, the viability of differentiated Caco-2 cells was assessed by visualising cell morphology using light microscopy, and staining cells with DAPI to count cell number.

$\mathrm{CuO}$ NMs stimulated a concentration dependent decrease in viability in undifferentiated cells. No significant difference was observed between the cytotoxicity of $\mathrm{CuO} \mathrm{NMs}$ and $\mathrm{CuSO}_{4}$. Whilst $\mathrm{CuO} \mathrm{NMs}$ and $\mathrm{CuSO}_{4}$ exhibit a similar level of toxicity, the $\mathrm{CuO}$ NMs tested in this study are not $100 \%$ soluble at $24 \mathrm{~h}$, and thus it is likely that the $\mathrm{CuO}$ NMs exhibit toxicity via particle and ion effects. Previous studies which has demonstrated that $\mathrm{Cu}$ ions are likely to contribute predominantly to the toxicity of $\mathrm{CuO}$ NMs in differentiated Caco-2 cells [51] although they reported that particle shape could 


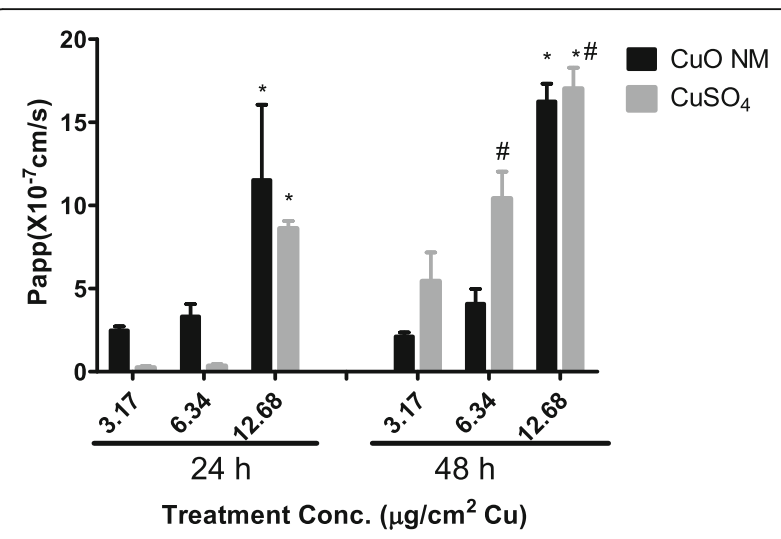

Fig. 6 Apparent permeability coefficient $\left(P_{a p p}\right)$ of $\mathrm{CuO} N M$ s and $\mathrm{CuSO}_{4}$ across Caco-2 cells. Following differentiation Caco-2 cells were exposed to cell culture medium (control, 0), CuO NMs or $\mathrm{CuSO}_{4}$ at concentration of $3.17,6.34$ or $12.68 \mu \mathrm{g} / \mathrm{cm}^{2} \mathrm{Cu}$ at the apical compartment for 24 and $48 \mathrm{~h}$. The concentration of $\mathrm{Cu}$ in the apical and basolateral compartment were determined by ICP-OES. Papp was calculated using Eq. 2 (refer to Methods). Data are expressed in mean $P_{a p p} \pm S E M \times 10^{-7} \mathrm{~cm} / \mathrm{s}(n=3)$. Significance $p<0.05$ are indicted by * for comparison of treatment concentration or \# for comparison of 24 and $48 \mathrm{~h}$ time point

also contribute to the toxicity of $\mathrm{CuO}$ NMs. Furthermore, whilst the $\mathrm{CuO}$ NMs tested in our study exhibited some solubility in the cell culture medium, it is also possible that some ion release occurs inside the cell following particle uptake (e.g. Trojan horse mechanism), contributing further to $\mathrm{Cu}$ mediated effects. In comparison with the findings of other published studies using Caco-2 cells $[50,69]$, it seems that this study has demonstrated higher toxicity of $\mathrm{CuO} \mathrm{NMs}$ than previously reported for $\mathrm{ZnO}(10 \mathrm{~nm}), \mathrm{SiO}_{2}(14 \mathrm{~nm}), \mathrm{TiO}_{2}$, iron oxides and $\mathrm{Ag}(20 \mathrm{~nm}) \mathrm{NMs}$ although this would require verification in side-by-side tests. Data from cytotoxicity testing was used to inform the selection of $\mathrm{CuO} \mathrm{NM}$ and $\mathrm{CuSO}_{4}$ concentrations to test when assessing impacts on differentiated cells. Of relevance is that imaging of cell morphology using light microscopy, and SEM revealed that there was a loss of cells in undifferentiated Caco-2 cells exposed to $\mathrm{CuO} \mathrm{NMs}$, which suggests that there was a reduction in cell viability. In contrast, no loss of differentiated cells was observed, which suggests that the concentrations and time point tested with $\mathrm{CuO}$ $\mathrm{NMs}$ were less toxic to the differentiated cells.

\section{Impact on barrier integrity}

We used measurement of TEER in combination with assessment of tight junction protein (ZO-1) staining and visualisation of cell morphology (SEM e.g. presence of microvilli) to confirm the differentiation status of Caco2 cells in our study. It is noteworthy that many other studies have only measured TEER values to assess the differentiation status of cells [51, 70], as this is an accepted method of confirming Caco-2 cell differentiation. However, in this study the use of three approaches (TEER measurement, tight junction staining and assessment of microvilli formation) provided a robust assessment not only of the differentiation status of the Caco-2 cells but also enabled the impact of $\mathrm{CuO}$ NMs on the intestinal barrier to be investigated.

Assessment of TEER over time has not been used as a measure of toxicity in previous studies which have investigated the impact of NMs on differentiated Caco- 2 cells. The TEER values of differentiated Caco- 2 cells showed a significant decrease from $9 \mathrm{~h}$ post-treatment with both $\mathrm{CuO}$ NMs and $\mathrm{CuSO}_{4}$ indicating a disruption in barrier integrity. To further study the impact of $\mathrm{CuO} \mathrm{NMs}$ and $\mathrm{CuSO}_{4}$ the tight junction protein (ZO-1) of differentiated Caco-2 cells was stained and imaged. A decrease in tight junction protein staining was observed in treated cells, which confirms that $\mathrm{CuO} N \mathrm{NM}$ and $\mathrm{CuSO}_{4}$ compromised the integrity of the Caco-2 monolayer. The images of $\mathrm{ZO}$ 1 staining after treatment with $\mathrm{CuO} \mathrm{NMs}$ and $\mathrm{CuSO}_{4}$ are less clear, but this is due to disruption of the tight junctions (confirmed by TEER and SEM) rather than poor staining or imaging. In addition, SEM imaging confirm the barrier perturbation and/or toxicity of $\mathrm{CuO} \mathrm{NMs}$ and $\mathrm{CuSO}_{4}$ on differentiated Caco-2 cell monolayer integrity. Impairment of barrier integrity has a number of implications for the function of the intestine. For example, the permeability of the intestinal barrier is likely to increase due to tight junction dysfunction, potentially permitting the transport of substances (e.g. chemicals, pathogens) across the intestinal barrier.

Translocation of NMs (polystyrene) across the intestinal barrier has been observed in vivo [71], however NM penetration (excluding nanocarriers) across the intestinal barrier has not been widely studied in vitro, despite the extensive use of the differentiated Caco-2 model to study the translocation of pharmaceuticals and pathogens $[54,55]$. Translocation across the intestinal barrier determines the bioavailability of NMs after oral exposure and could be affected by NMs physico-chemical properties including size, charge, time and the experimental set up (e.g. concentration, time point) [72, 73]. In this study, it was demonstrated that $\mathrm{CuO} \mathrm{NMs}$ and $\mathrm{CuSO}_{4}$ translocated across the intestinal barrier in a concentration and time dependent manner. The transport of $\mathrm{Cu}$ is likely to be facilitated by the ability of $\mathrm{CuO} N M$ and $\mathrm{CuSO}_{4}$ to disrupt barrier integrity. More specifically, a loss of tight junction function (as indicated by measurement of TEER value and tight junction protein staining in this study) is likely to enhance paracellular NM translocation. In vitro studies have demonstrated up to $7.8 \%$ and $0.8 \%$ translocation of 50 and $100 \mathrm{~nm}$ charged polystyrene NMs respectively using Caco-2 co-culture intestinal epithelial 
cell models [72] which is similar to the findings of this study.

At the lowest concentration of $\mathrm{CuO} \mathrm{NMs}$ and $\mathrm{CuSO}_{4}$ tested summation of copper concentration in apical, basolateral and cell adds up to approximately $100 \%$ of the exposure concentration. However, at higher concentrations of $\mathrm{CuO} \mathrm{NMs} \mathrm{and} \mathrm{CuSO}_{4}$ it was not possible to recover all copper. It is possible that the increase in copper concentration activates the synthesis of thiol containing proteins including metalothionein [74, 75] and an indiscriminate binding of copper to the thiol group may occur leading to reduction in detectable copper ion in the apical, basolateral and cell compartments. In addition, the copper may have bound to plastic used in the experiment [76, 77] (e.g. cell culture plates and the insert polycarbonate membrane) to prevent its detection. Other possible point of loss of copper include washing of the cell monolayer with PBS after aspiration of cell medium before cell digestion.

The $\mathrm{P}_{\text {app }}$ is frequently used to predict translocation of orally absorbed pharmaceuticals and xenobiotics, especially in drug discovery [55]. The mechanism of translocation is likely to be via passive diffusion if the $\mathrm{P}_{\mathrm{app}}$ value did not change with increasing concentration of the test substance in the apical compartment [59]. $\mathrm{P}_{\text {app }}$ values less than $1 \times 10^{-6} \mathrm{~cm} / \mathrm{s}$ are an indication of malabsorption in drug development while $\mathrm{P}_{\text {app }}$ values greater than $10 \times 10^{-6} \mathrm{~cm} / \mathrm{s}$ represent good absorption [78].

In this study, the $\mathrm{P}_{\mathrm{app}}$ values of differentiated Caco-2 cells treated with all concentrations of $\mathrm{CuO} N M s$ and $\mathrm{CuSO}_{4}$ for $24 \mathrm{~h}$ were less than $1 \times 10^{-6} \mathrm{~cm} / \mathrm{s}$. In addition, at $48 \mathrm{~h}$, only those cells treated with 6.34 and $12.68 \mu \mathrm{g} / \mathrm{cm}^{2} \mathrm{CuSO}_{4}$ and $12.68 \mu \mathrm{g} / \mathrm{cm}^{2}$ of $\mathrm{CuO}$ NMs were greater than $1 \times 10^{-6} \mathrm{~cm} / \mathrm{s}$ but less than $10 \times 10^{-6} \mathrm{~cm} / \mathrm{s}$. The $\mathrm{P}_{\text {app }}$ value at 24 and $48 \mathrm{~h}$ were higher than $\mathrm{P}_{\text {app }}$ value of mannitol $\left(\sim 5.0 \times 10^{-7} \mathrm{~cm} / \mathrm{s}\right)$ on differentiated Caco-2 cells [45]. This suggests that both $\mathrm{CuO} \mathrm{NMs} \mathrm{and} \mathrm{CuSO}_{4}$ are generally malabsorbed (i.e. are not translocating across the intestinal barrier) at lower concentrations at $24 \mathrm{~h}$ post exposure. Therefore, it could be inferred that translocation of $\mathrm{CuO} \mathrm{NMs} \mathrm{or} \mathrm{CuSO}_{4}$, requires tight junction stress and dysfunction.

\section{IL-8 production}

$\mathrm{CuO} \mathrm{NMs}$ and $\mathrm{CuSO}_{4}$ stimulated a concentration and time dependent increase in IL- 8 protein production in this study in both undifferentiated and differentiated Caco-2 cells. A wide range of cell types produce interleukin 8 (IL-8), a member of the chemokine superfamily whose primary function is to mediate the activation and migration of neutrophils from peripheral blood to tissues [79]. IL-8 is involved in initiation and amplification of inflammatory processes in response to pathogenic invasion, tumour necrosis factor, cellular stress and NMs [79-81]. Production of IL-8 was much greater in undifferentiated Caco-2 cells compared to differentiated Caco-2 cells at the same concentration of $\mathrm{Cu}$ in the both models, which is similar to the findings of Gerloff et al. [50] who investigated the toxicity of $\mathrm{SiO}_{2}$ and $\mathrm{ZnO}$ NMs. This could be attributed to the more robust nature of differentiated Caco- 2 cells as they possess most of the characteristics of human intestinal enterocytes [43]. The lower level of IL-8 production in differentiated Caco-2 cells did not appear to be a consequence of a loss of cell viability in our study. Indeed, for the controls (exposed to cell culture medium) there were higher numbers of cells observed for differentiated cells than undifferentiated cells. Despite this, there was less IL-8 production by control differentiated cells, when compared to that observed for undifferentiated cells. Our findings suggest that toxicity may be over-estimated if undifferentiated cells are used in isolation to investigate NMs toxicity. Therefore, differentiated Caco-2 cells are perhaps more appropriate for toxicity studies, when investigating cytokine production.

Another striking observation is that a peak production of IL-8 was observed at $6.34 \mu \mathrm{g} / \mathrm{cm}^{2} \mathrm{Cu}$ with a decrease in production observed at $12.68 \mu \mathrm{g} / \mathrm{cm}^{2} \mathrm{Cu}$ compared to the lower concentration. The peak IL- 8 production was observed at the BMD 20 concentration with the decreased IL-8 production at higher concentration likely the consequences of cell death. IL-8 in the control and basolateral compartment fell below the detection limit $(31.3 \mathrm{pg} / \mathrm{ml})$, as observed by others (e.g. [51].

\section{NM physico-chemical properties and toxicity}

NM physicochemical properties such as particle size and size distribution, agglomeration state, shape, crystal structure, chemical composition, surface area, surface chemistry, surface charge, and porosity influence the toxicity of NMs $[26,82]$. The primary particle size of the $\mathrm{CuO}$ NMs investigated in this study is $\sim 10 \mathrm{~nm}$ [25]. Immediately following dispersion in biological medium, the hydrodynamic diameter of the NMs was $\sim 157 \mathrm{~nm}$, which suggested that the NMs were agglomerated. Existing studies have also demonstrated that the dispersion medium can impact on the physico-chemical properties of NMs [82, 83]. Following incubation at $37^{\circ} \mathrm{C}$ for $24 \mathrm{~h}$, the hydrodynamic diameter of the NMs suspension was $\sim 24 \mathrm{~nm}$. This suggests that the NMs may become less agglomerated and/or dissolve over time.

The dissolution of $\mathrm{CuO} \mathrm{NMs}$ was measured in cell culture medium in this study, and has been previously quantified in Gamble's solution [25]. The observed level of dissociated $\mathrm{Cu}^{2+}$ from $\mathrm{CuO}$ NMs dispersed in MEM (47.79 and $53.53 \%$ at 1 and $24 \mathrm{~h}$ respectively) and DMEM (59.91 and $67.41 \%$ at 1 and $24 \mathrm{~h}$ respectively) analysed using ICP-OES and similarity in behaviour of $\mathrm{CuSO}_{4}$ and $\mathrm{CuO}$ NMs in all the studies performed 
suggest that the effect observed by $\mathrm{CuO}$ NMs are ion mediated. However, there could be some effect exerted by the particle form of copper oxide. The dissolution of $\mathrm{CuO}$ NMs over time has also been observed for spherical, rod and spindle-shaped platelet $\mathrm{CuO}$ NMs using 51, 48 and $61 \mathrm{mg} / \mathrm{L}$ respectively in complete serum free cell culture medium after $20 \mathrm{~h}$ incubation [84].

\section{Conclusion}

This results of this study demonstrate that both $\mathrm{CuO}$ $\mathrm{NMs}$ and $\mathrm{CuSO}_{4}$ impact to a similar degree on the TEER, cell morphology, tight junction integrity, translocation and IL-8 production of differentiated Caco- 2 cells in vitro. The comparable results between $\mathrm{CuO} \mathrm{NMs} \mathrm{and} \mathrm{CuSO}_{4}$ suggest that NMs induced effects is at least in part, ion mediated. Importantly, $\mathrm{CuO} \mathrm{NMs}$ are no more potent than the $\mathrm{CuSO}_{4}$, which is important for risk assessment considerations.

Our data demonstrate that whilst more expensive and time intensive the differentiated Caco- 2 model should be prioritised over undifferentiated model when assessing the impacts of NMs on the GI tract. In future studies, it is recommended that differentiated cells be used in the first instance to screen the cytotoxicity of NMs in order to rapidly provide information on their toxic potency and to identify sub-lethal concentrations to test in more comprehensive studies, which investigate the mechanism of toxicity. Future studies will also need to use more complicated in vitro intestinal models (e.g. that incorporate mucus secreting cells, inflammatory cells and $M$ cells) to test a wider panel of NMs to identify the most appropriate model for in-depth study of NMs toxicity to GI tract.

\section{Additional files}

Additional file 1: CuO NM dissolution study. (DOCX $12 \mathrm{~kb}$ )

Additional file 2: ZO-1 staining of undifferentiated Caco-2 cells. (DOCX $1046 \mathrm{~kb}$ )

\section{Abbreviations}

BMD: Benchmark dose-response; CuO NMs: Copper oxide nanomaterials; $\mathrm{CuSO}_{4}$ : Copper sulphate salt; DLS: Dynamic Light Scattering; ELISA: Enzymelinked immunosorbent assay; FBS: Fetal bovine serum; ICP-OES: Inductive Coupled Plasma Optical Emission Spectrometry; IL-8: Interleukin-8; PBS: Phosphate buffered saline; TEER: Transepithelial electrical potential; TEM: Transmission electron microscopy

\section{Acknowledgements}

The Authors are grateful to Vice Chancellor of Enugu State University of Science and Technology Enugu Nigeria for granting Victor Chibueze Ude study leave and Tertiary Education Trust Fund Nigeria for paying his PhD tuition fees. We thank SUN EU FP 7 funded project (Grant number 604305) for providing us with CuO NMs. We also thank Dr. Lorna Eades (University of Edinburgh) for helping in ICP-OES analysis.

\section{Funding}

Enugu State University of Science and Technology Enugu Nigeria granting Victor Chibueze Ude study leave and Tertiary Education Trust Fund Nigeria paid his PhD tuition fees. The FP 7 funded project SUN (Grant number 604305) funded the dissolution studies. All funding bodies had no influence on the design of the study, collection, analysis and interpretation of data or in writing the manuscript.

\section{Availability of data and materials}

Data supporting the findings are presented within the manuscript and additional files. Raw data files are available on request to the corresponding author.

\section{Authors' contributions}

VCU participated in the design of the study, carried out all the experiments, analysed the data and drafted the manuscript. DB contributed in the ICPOES analyses and statistical analyses and provided expert advice on the study. NK assisted with the cell culture and provided expert advice on the study. LV performed ICP-OES analysis of the CUO NMs to assess solubility. VS participated in the study design, reviewing of the drafted manuscript and provided expert advice on the study. $\mathrm{HJ}$ participated in the study design and supervising the experiment, reading and reviewing the drafted manuscript and provided expert advice on the study. All authors read and approved the final manuscript.

Ethics approval and consent to participate

Not applicable.

\section{Consent for publication}

Not applicable.

\section{Competing interests}

The authors declare that they have no competing interests and are responsible for the content and data of this manuscript.

\section{Publisher's Note}

Springer Nature remains neutral with regard to jurisdictional claims in published maps and institutional affiliations.

\section{Author details}

${ }^{1}$ Nano Safety Research Group, School of Engineering and Physical Sciences, Institute of Biological Chemistry, Biophysics and Bioengineering, Heriot-Watt University, Edinburgh EH14 4AS, UK. ${ }^{2}$ CNR-ISTEC Faenza, Via Granarolo, 64 -, 48018 Faenza, RA, Italy.

Received: 7 September 2016 Accepted: 14 August 2017 Published online: 23 August 2017

References

1. Desai V, Kaler SG. Role of copper in human neurological disorders1-3. Am J Clin Nutr. 2008;88:855S-8S

2. Araya M, Olivares M, Pizarro F, González M, Speisky H, Uauy R. Gastrointestinal symptoms and blood indicators of copper load in apparently healthy adults undergoing controlled copper exposure. Am J Clin Nutr. 2003;77:646-50.

3. Erickson KL, Medina EA, Hubbard NE. Micronutrients and Innate Immunity. J Infect Dis. 2000;182(Suppl 1):S5-10.

4. Muñoz C, López M, Olivares M, Pizarro F, Arredondo M, Araya M. Differential response of interleukin-2 production to chronic copper supplementation in healthy humans. Eur Cytokine Netw. 2005;16(4):261-5.

5. Kaler SG. Metabolic and molecular bases of Menkes disease and occipital horn syndrome. Pediatr Dev Pathol. 1998;1:85-98.

6. Gaggelli E, Kozlowski H, Valensin D, Valensin G. Copper homeostasis and neurodegenerative disorders (Alzheimer's, prion, and Parkinson's diseases and amyotrophic lateral sclerosis). Chem Rev. 2006;106:1995-2044.

7. Ellingsen DG, Horn N, JAN A. CHAPTER 26 - Copper. In: Handbook on the Toxicology of Metals. Third ed. Burlington: Academic Press; 2007. p. 529-46.

8. Gotteland M, Araya M, Pizarro F, Olivares M. Effect of acute copper exposure on gastrointestinal permeability in healthy volunteers. Dig Dis Sci. 2001;46(9):1909-14.

9. Bouwmeester H, Dekkers S, Noordam MY, Hagens WI, Bulder AS, de Heer C, ten Voorde SECG, Wijnhoven SWP, Marvin HJP, Sips AJAM. Review of health 
safety aspects of nanotechnologies in food production. Regul Toxicol Pharmacol. 2009:53(1):52-62.

10. Aueviriyavit $S$, Phummiratch D, Maniratanachote R. Mechanistic study on the biological effects of silver and gold nanoparticles in Caco-2 cellsinduction of the Nrf2/HO-1 pathway by high concentrations of silver nanoparticles. Toxicol Lett. 2014;224:73-83.

11. Gabbay J. Copper oxide impregnated textiles with potent biocidal activities. J Ind Text. 2006;35(4):323-35.

12. Ren G, Hu D, Cheng EW, Vargas-Reus MA, Reip P, Allaker RP. Characterisation of copper oxide nanoparticles for antimicrobial applications. Int J Antimicrob Agents. 2009;33(6):587-90

13. Aruoja V, Dubourguier H-C, Kasemets K, Kahru A. Toxicity of nanoparticles of $\mathrm{CuO}, \mathrm{ZnO}$ and $\mathrm{TiO} 2$ to microalgae Pseudokirchneriella subcapitata. Sci Total Environ. 2009;407(4):1461-8.

14. Longano D, Ditaranto N, Cioffi N, Di Niso F, Sibillano T, Ancona A, Conte A, Del Nobile MA, Sabbatini L, Torsi L. Analytical characterization of lasergenerated copper nanoparticles for antibacterial composite food packaging. Anal Bioanal Chem. 2012;403(4):1179-86.

15. Civardi C, Schubert M, Fey A, Wick P, Schwarze FWMR. Micronized copper wood preservatives: efficacy of ion, Nano, and bulk copper against the Brown rot fungus Rhodonia placenta. PLoS One. 2015;10(11):e0142578.

16. Soltani A, Vahed BK, Mardoukhi A, Mäntysalo M. Laser sintering of copper nanoparticles on top of silicon substrates. Nanotechnology. 2016;27(3): 035203.

17. Chang H, Jwo CS, Lo CH, Tsung TT, Kao MJ, Lin HM. Rheology of CuO nanoparticle suspension prepared by ASNSS. Rev AdvMater sci. 2005;10:128-32

18. Cheng CW, Chen JK. Femtosecond laser sintering of copper nanoparticles. Applied Physics A. 2016;122(4):1-8.

19. Zenou M, Ermak O, Saar A, Kotler Z. Laser sintering of copper nanoparticles. J Phys D Appl Phys. 2014;47(2):025501.

20. Ahamed M, Alhadlaq HA, Khan MAM, Karuppiah P, Al-Dhabi NA. Synthesis, characterization, and antimicrobial activity of copper oxide nanoparticles. J Nanomater. 2014;2014:1-4.

21. Sambale F, Wagner S, Stahl F, Khaydarov RR, Scheper T, Bahnemann D. Investigations of the toxic effect of silver nanoparticles on mammalian cell lines. J Nanomater. 2015;2015:9.

22. Asghari S, Johari SA, Lee JH, Kim YS, Jeon YB, Choi HJ, Moon MC, Yu IJ. Toxicity of various silver nanoparticles compared to silver ions in Daphnia Magna. J Nanobiotechnology. 2012;10(1):14.

23. Georgantzopoulou A, Serchi T, Cambier S, Leclercq CC, Renaut J, Shao J, Kruszewski M, Lentzen E, Grysan P, Eswara S, et al. Effects of silver nanoparticles and ions on a co-culture model for the gastrointestinal epithelium. Part Fibre Toxicol. 2016;13(1):1-17.

24. Ahamed M, Akhtar MJ, Alhadlaq HA, Alrokayan SA. Assessment of the lung toxicity of copper oxide nanoparticles: current status. Nanomedicine. 2015;10(15):2365-77.

25. Gosens I, Cassee FR, Zanella M, Manodori L, Brunelli A, Costa AL, Bokkers BGH, de Jong WH, Brown D, Hristozov D, et al. Organ burden and pulmonary toxicity of nano-sized copper (II) oxide particles after short-term inhalation exposure. Nanotoxicology. 2016:1-12.

26. Karlsson HL, Cronholm P, Gustafsson J, Möller L. Copper oxide nanoparticles are highly toxic: a comparison between metal oxide nanoparticles and carbon nanotubes. Chem Res Toxicol. 2008;21 (9):1726-32.

27. Bondarenko O, Juganson K, Ivask A, Kasemets K, Mortimer M, Kahru A. Toxicity of ag, $\mathrm{CuO}$ and $\mathrm{ZnO}$ nanoparticles to selected environmentally relevant test organisms and mammalian cells in vitro: a critical review. Arch Toxicol. 2013;87(7):1181-200.

28. Lei R, Wu C, Yang B, Ma H, Shi C, Wang Q, Wang Q, Yuan Y, Liao M. Integrated metabolomic analysis of the nano-sized copper particle-induced hepatotoxicity and nephrotoxicity in rats: a rapid in vivo screening method for nanotoxicity. Toxicol Appl Pharmacol. 2008;232(2):292-301.

29. Siddiqui MA, Alhadlaq HA, Ahmad J, Al-Khedhairy AA, Musarrat J, Ahamed M. Copper oxide nanoparticles induced mitochondria mediated apoptosis in human hepatocarcinoma cells. PLoS One. 2013;8(8):e69534.

30. Chen Z, Meng H, Xing G, Chen C, Zhao Y, Jia G, Wang T, Yuan H, Ye C, Zhao $F$, et al. Acute toxicological effects of copper nanoparticles in vivo. Toxicol Lett. 2006;163(2):109-20.

31. Chen D, Zhang D, Yu JC, Chan KM. Effects of Cu2O nanoparticle and CuCl2 on zebrafish larvae and a liver cell-line. Aquat Toxicol. 2011;105(3-4):344-54.
32. Meng $H$, Chen Z, Xing G, Yuan H, Chen C, Zhao F, Zhang C, Zhao Y. Ultrahigh reactivity provokes nanotoxicity: explanation of oral toxicity of nano-copper particles. Toxicol Lett. 2007;175(1-3):102-10.

33. Nel A, Xia T, Mädler L, Li N. Toxic potential of materials at the Nanolevel: Science. 2006;311(5761):622-7.

34. Hoet PH, Brüske-Hohlfeld I, Salata OV. Nanoparticles - known and unknown health risks. J Nanobiotechnology. 2004;2(1):1-15.

35. Takenaka S, Karg E, Roth C, Schulz H, Ziesenis A, Heinzmann U, Schramel P, Heyder J. Pulmonary and systemic distribution of inhaled ultrafine silver particles in rats. Environ Health Perspect. 2001;109(Suppl 4):547-51.

36. Aitken RJ, Chaudhry MQ, Boxall AB, Hull M. Manufacture and use of nanomaterials: current status in the UK and global trends. Occup Med. 2006; 56(5):300-6.

37. Peixe TS, Souza Nascimento ED, Schofield KL, Arcuri ASA, Bulcão RP. Nanotoxicology and exposure in the occupational setting. Occup Dis Environ Med. 2015;03(03):35-48.

38. Stone V, Pozzi-Mucelli S, Tran L, Aschberger K, Sabella S, Vogel U, Poland C, Balharry D, Fernandes T, Gottardo S, et al. ITS-NANO - Prioritising nanosafety research to develop a stakeholder driven intelligent testing strategy. Part Fibre Toxicol. 2014;1:9.

39. House of the Lords. Nanotechnologies and Food, vol. 1. London: The Stationery Office Limited; 2009. p. 1-112.

40. Burden N, Aschberger K, Chaudhry Q, Clift MJD, Doak SH, Fowler P, Johnston H, Landsiedel R, Rowland J, Stone V. The 3Rs as a framework to support a 21 st century approach for nanosafety assessment. Nano Today. 2017;12:10-13

41. Fogh J, Fogh JM, Orfeo T. One hundred and twenty-seven cultured human tumor cell lines producing tumors in nude mice. J Natl Cancer Inst. 1977:59(1):221-6.

42. Sambuy Y, Ferruzza S, Ranaldi G, De Angelis I. Intestinal cell culture models: applications in toxicology and pharmacology, vol. 17. Netherlands: C Kluwer Academic Publishers; 2001.

43. Sambuy Y, De Angelis I, Ranaldi G, Scarino ML, Stammati A, Zucco F. The Caco-2 cell line as a model of the intestinal barrier: influence of cell and culture-related factors on Caco-2 cell functional characteristics. Cell Biol Toxicol. 2005:21:1-26.

44. Natoli M, Leoni BD, D'Agnano I, D'Onofrio M, Brandi R, Arisi I, Zucco F, Felsani A. Cell growing density affects the structural and functional properties of Caco-2 differentiated monolayer. J Cell Physiol. 2011:226(6):1531-43.

45. Ferruzza S, Rossi C, Scarino ML, Sambuy Y. A protocol for in situ enzyme assays to assess the differentiation of human intestinal Caco-2 cells. Toxicol In Vitro. 2012;26(8):1247-51.

46. Gerloff K, Albrecht C, Boots AW, Förster I, Schins RPF. Cytotoxicity and oxidative DNA damage by nanoparticles in human intestinal Caco-2 cells. Nanotoxicology. 2009;3(4):355-64.

47. Abbott Chalew TE, Schwab KJ. Toxicity of commercially available engineered nanoparticles to Caco-2 and SW480 human intestinal epithelial cells. Cell Biol Toxicol. 2013:29(2):101-16.

48. van der Zande M, Undas AK, Kramer E, Monopoli MP, Peters RJ, Garry D, Antunes Fernandes EC, Hendriksen PJ, Marvin HJP, Peijnenburg AA, et al. Different responses of Caco-2 and MCF-7 cells to silver nanoparticles are based on highly similar mechanisms of action. Nanotoxicology. 2016;10(10): $1431-41$.

49. Tarantini A, Lanceleur R, Mourot A, Lavault MT, Casterou G, Jarry G, Hogeveen $\mathrm{K}$, Fessard V. Toxicity, genotoxicity and proinflammatory effects of amorphous nanosilica in the human intestinal Caco-2 cell line. Toxicol in Vitro. 2015;29(2):398-407.

50. Gerloff K, Pereira DIA, Faria N, Boots AW, Kolling J, Förster I, Albrecht C, Powell JJ, Schins RPF. Influence of simulated gastrointestinal conditions on particle-induced cytotoxicity and interleukin-8 regulation in differentiated and undifferentiated Caco-2 cells. Nanotoxicology. 2013; 7(4):353-66.

51. Piret JP, Vankoningsloo S, Mejia J, Noel F, Boilan E, Lambinon F, Zouboulis CC, Masereel B, Lucas S, Saout C, et al. Differential toxicity of copper (II) oxide nanoparticles of similar hydrodynamic diameter on human differentiated intestinal Caco-2 cell monolayers is correlated in part to copper release and shape. Nanotoxicology. 2012;6(7):789-803.

52. Ferruzza S, Rossi C, Scarino ML, Sambuy Y. A protocol for differentiation of human intestinal Caco-2 cells in asymmetric serum-containing medium Toxicol in Vitro. 2012;26(8):1252-5. 
53. Fisichella M, Berenguer F, Steinmetz G, Auffan M, Rose J, Prat O. Toxicity evaluation of manufactured $\mathrm{CeO} 2$ nanoparticles before and after alteration: combined physicochemical and whole-genome expression analysis in Caco-2 cells. BMC Genomics. 2014;15:700.

54. Lubelska K, Misiewicz-Krzemińska I, Milczarek M, Krzysztoń-Russjan J, Anuszewska E, Modzelewska K, Wiktorska K. Isothiocyanate-drug interactions in the human adenocarcinoma cell line Caco-2. Mol Cell Biochem. 2012;367(1):19-29.

55. Hubatsch I, Ragnarsson EGE, Artursson P. Determination of drug permeability and prediction of drug absorption in Caco-2 monolayers. Nat Protocols. 2007;2(9):2111-9.

56. Lefebvre DE, Venema K, Gombau L, Valerio LG Jr, Raju J, Bondy GS, Bouwmeester $\mathrm{H}$, Singh RP, Clippinger AJ, Collnot EM, et al. Utility of models of the gastrointestinal tract for assessment of the digestion and absorption of engineered nanomaterials released from food matrices. Nanotoxicology. 2015;9(4):523-42.

57. Chen X-M, Elisia I, Kitts DD. Defining conditions for the co-culture of Caco-2 and HT29-MTX cells using Taguchi design. J Pharmacol Toxicol Methods. 2010;61(3):334-42.

58. Beloqui A, des Rieux A, Préat V. Mechanisms of transport of polymeric and lipidic nanoparticles across the intestinal barrier. Adv Drug Deliv Rev. 2016;106(Part B):242-255.

59. Chen G, Lianqin Z, Fenghua Z, Fang Z, Mingming S, Kai H. Comparative evaluation of nano-CuO crossing Caco-2 cell monolayers and cellular uptake. J Nanopart Res. 2015;17(4):1-10.

60. Chang H-J, Choi S-W, Ko S-H, Chun H-S. Effect of particle size of zinc oxides on cytotoxicity and cell permeability in Caco-2 cells. J Food Sci Nutr. 2011;16(2):174-8

61. Schleh C, Semmler-Behnke M, Lipka J, Wenk A, Hirn S, Schäffler M, Schmid G, Simon U, Kreyling WG. Size and surface charge of gold nanoparticles determine absorption across intestinal barriers and accumulation in secondary target organs after oral administration. Nanotoxicology. 2012;6(1):36-46.

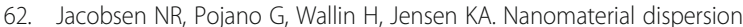
protocol for toxicological studies in ENPRA. Internal ENPRA Project Report. The National 885 Research Centre for the Working Environment 2010.

63. Horobin RW. How Romanowsky stains work and why they remain valuable including a proposed universal Romanowsky staining mechanism and a rational troubleshooting scheme. Biotech Histochem. 2011;86(1):36-51.

64. Bolea E, Jimenez-Lamana J, Laborda F, Abad-Alvaro I, Blade C, Arola L, Castillo JR. Detection and characterization of silver nanoparticles and dissolved species of silver in culture medium and cells by AsFIFFF-UV-visICPMS: application to nanotoxicity tests. Analyst. 2014;139(5):914-22.

65. des Rieux A, Fievez V, Theate I, Mast J, Preat V, Schneider YJ. An improved in vitro model of human intestinal follicle-associated epithelium to study nanoparticle transport by M cells. Eur J Pharm Sci. 2007;30(5):380-391.

66. Han X, Gelein R, Corson N, Wade-Mercer P, Jiang J, Biswas P, Finkelstein JN, Elder A, Oberdörster G: Validation of an LDH assay for assessing nanoparticle toxicity. Toxicology 2011, 287(0):99-104.

67. Stone V, Johnston HJ, Balharry D, Gernand JM, Gulumian M. Approaches to develop alternative testing strategies to inform human health risk assessment of nanomaterials. Risk Anal. 2016;36(8):1538-50.

68. Chen C-C, Chen JJ. Benchmark dose calculation for ordered categorical responses. Risk Anal. 2014;34(8):1435-47.

69. Bouwmeester H, Poortman J, Peters RJ, Wijma E, Kramer E, Makama S, Puspitaninganindita K, Marvin HJP, Peijnenburg AACM, Hendriksen PJM. Characterization of translocation of silver nanoparticles and effects on whole-genome gene expression using an in vitro intestinal epithelium Coculture model. ACS Nano. 2011:5(5):4091-103.

70. Nishitani Y, Zhang L, Yoshida M, Azuma T, Kanazawa K, Hashimoto T, Mizuno M. Intestinal anti-inflammatory activity of lentinan: influence on IL-8 and TNFR1 expression in intestinal epithelial cells. PLoS One. 2013;8(4):e62441.

71. Walczak AP, Hendriksen PJM, Woutersen RA, van der Zande M, Undas AK, Helsdingen $\mathrm{R}$, van den Berg HHJ, Rietjens IMCM, Bouwmeester H. Bioavailability and biodistribution of differently charged polystyrene nanoparticles upon oral exposure in rats. J Nanopart Res. 2015;17(5):231.

72. Walczak AP, Kramer E, Hendriksen PJM, Tromp P, Helsper JPFG, van der Zande M, Rietjens IMCM, Bouwmeester H. Translocation of differently sized and charged polystyrene nanoparticles in in vitro intestinal cell models of increasing complexity. Nanotoxicology. 2015;9(4):453-61.
73. Bellmann S, Carlander D, Fasano A, Momcilovic D, Scimeca JA, Waldman WJ, Gombau L, Tsytsikova L, Canady R, Pereira DI, et al. Mammalian gastrointestinal tract parameters modulating the integrity, surface properties, and absorption of food-relevant nanomaterials. Wiley Interdiscip Rev Nanomed Nanobiotechnol. 2015;7(5):609-22.

74. Gaetke LM, Chow-Johnson HS, Chow CK. Copper: toxicological relevance and mechanisms. Arch Toxicol. 2014;88(11):1929-38.

75. Letelier ME, Lepe AM, Faúndez M, Salazar J, Marín R, Aracena P, Speisky $\mathrm{H}$. Possible mechanisms underlying copper-induced damage in biological membranes leading to cellular toxicity. Chem Biol Interact. 2005;151(2):71-82

76. Malysheva A, Ivask A, Hager C, Brunetti G, Marzouk ER, Lombi E, Voelcker NH. Sorption of silver nanoparticles to laboratory plastic during (eco)toxicological testing. Nanotoxicology. 2016;10(4):385-90.

77. Sekine R, Khurana K, Vasilev K, Lombi E, Donner E. Quantifying the adsorption of ionic silver and functionalized nanoparticles during ecotoxicity testing: test container effects and recommendations. Nanotoxicology. 2015;9(8):1005-12.

78. Yee S. In vitro permeability across Caco-2 cells (colonic) can predict in vivo (small intestinal) absorption in man-fact or myth. Pharm Res. 1997;14(6):763-6.

79. Puthothu B, Krueger M, Heinze J, Forster J, Heinzmann A. Impact of IL8 and IL8-receptor alpha polymorphisms on the genetics of bronchial asthma and severe RSV infections. Clin Mol Allergy. 2006;4(1):1-6.

80. Hoffmann E, Dittrich-Breiholz O, Holtmann H, Kracht M. Multiple control of interleukin-8 gene expression. J Leukoc Biol. 2002;72(5):847-55.

81. Kermanizadeh A, Pojana G, Gaiser BK, Birkedal R, Bilanicova D, Wallin H, Jensen KA, Sellergren B, Hutchison GR, Marcomini A, et al. In vitro assessment of engineered nanomaterials using a hepatocyte cell line: cytotoxicity, pro-inflammatory cytokines and functional markers. Nanotoxicology. 2013;7(3):301-13.

82. Oberdörster G, Maynard A, Donaldson K, Castranova V, Fitzpatrick J, Ausman K, Carter J, Karn B, Kreyling W, Lai D, et al. Principles for characterizing the potential human health effects from exposure to nanomaterials: elements of a screening strategy. Part Fibre Toxicol. 2005;2(1):1-35.

83. Kang $T$, Guan $R$, Chen $X$, Song $Y$, Jiang $H$, Zhao J. In vitro toxicity of different-sized ZnO nanoparticles in Caco-2 cells. Nanoscale Res Lett. 2013;8:496.

84. Misra SK, Nuseibeh S, Dybowska A, Berhanu D, Tetley TD, Valsami-Jones E. Comparative study using spheres, rods and spindle-shaped nanoplatelets on dispersion stability, dissolution and toxicity of CuO nanomaterials. Nanotoxicology. 2014;8(4):422-32.

\section{Submit your next manuscript to BioMed Central and we will help you at every step:}

- We accept pre-submission inquiries

- Our selector tool helps you to find the most relevant journal

- We provide round the clock customer support

- Convenient online submission

- Thorough peer review

- Inclusion in PubMed and all major indexing services

- Maximum visibility for your research

Submit your manuscript at www.biomedcentral.com/submit 